University of Rhode Island

DigitalCommons@URI

Open Access Master's Theses

2019

\title{
IMPACT OF FABRIC PARAMETERS ON THE TEXTILE DIELECTRIC LAYER OF A CAPACITIVE PRESSURE SENSOR
}

Jaime Fine

University of Rhode Island, shimrafine@gmail.com

Follow this and additional works at: https://digitalcommons.uri.edu/theses

\section{Recommended Citation}

Fine, Jaime, "IMPACT OF FABRIC PARAMETERS ON THE TEXTILE DIELECTRIC LAYER OF A CAPACITIVE PRESSURE SENSOR" (2019). Open Access Master's Theses. Paper 1495.

https://digitalcommons.uri.edu/theses/1495

This Thesis is brought to you for free and open access by DigitalCommons@URI. It has been accepted for inclusion in Open Access Master's Theses by an authorized administrator of DigitalCommons@URI. For more information, please contact digitalcommons-group@uri.edu. 
IMPACT OF FABRIC PARAMETERS ON THE TEXTILE DIELECTRIC LAYER OF

A CAPACITIVE PRESSURE SENSOR

$\mathrm{BY}$

JAIME FINE

A THESIS SUBMITTED IN PARTIAL FULFILLMENT OF THE REQUIREMENTS FOR THE DEGREE OF

MASTER OF SCIENCE

IN

TEXTILE SCIENCE

UNIVERSITY OF RHODE ISLAND

2019 
MASTER OF SCIENCE IN TEXTILE SCIENCE

OF

JAIME FINE

APPROVED:

Thesis Committee:

Major Professor Martin Bide

Saheli Goswami

Kunal Mankodiya

Nasser H. Zawia

DEAN OF THE GRADUATE SCHOOL

UNIVERSITY OF RHODE ISLAND

2019 


\begin{abstract}
Porosity variations in a non-textile dielectric layer are known to impact sensor output in a capacitive pressure sensor. There are many benefits to using completely textile-based sensors for wearable technology, such as comfort, washability, cost, and ease of integration. Therefore, this study intended to establish if differences in structural parameters and air permeability of a textile-based dielectric layer could influence sensor output as well. The thickness of various polyester, nylon, and acrylic fabrics was determined via ASTM D1777-96 (2015): Standard Test Method for Thickness of Textile Materials. Several fabrics of similar thickness within each fiber group were selected to be conditioned in accordance with ASTM D1776: Standard Practice for Conditioning and Testing Textiles before being tested for air permeability under the guidelines from ASTM D737-18: Standard Test Method for Air Permeability of Textile Fabrics.

The chosen fabrics were cut to $108 \times 108 \mathrm{~mm}$. These textile samples were sandwiched between two $2 \times 102 \times 102 \mathrm{~mm}$ stainless steel plates and attached to an LCR meter. Weight was applied to these sensors in $500 \mathrm{~g}$ increments up to $4000 \mathrm{~g}$ and then removed in $500 \mathrm{~g}$ increments back to $0 \mathrm{~g}$. Six trials were conducted for each fabric. Hysteresis error, sensitivity, linearity error, and repeatability were calculated from the data. The results showed that structural variations did cause distinct differences in sensor output. However, there was not enough control in the structural variations to determine specific trends. Further testing with more controlled structural variations would also be necessary to determine the impact of air permeability.
\end{abstract}




\section{ACKNOWLEDGMENTS}

I would like to take the time to thank my major professor, Dr. Martin Bide, for his patience and guidance throughout the whole process. I would also like to thank my committee members, Dr. Saheli Goswami and Dr. Kunal Mankodiya for their insight.

I am grateful to Kenyon Industries allowing me to test in their facilities and to Mohawk Fabrics for supplying me with some fabric. 


\section{TABLE OF CONTENTS}

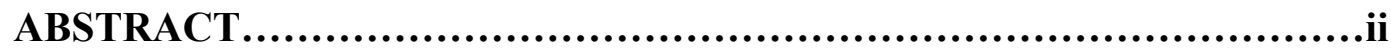

ACKNOWLEDGEMENTS.......................................................iii

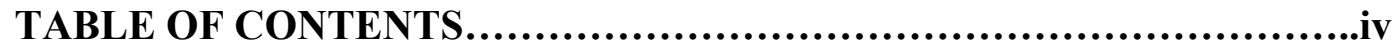

LIST OF TABLES........................................................v

LIST OF FIGURES......................................................vi

CHAPTER 1..........................................................................1

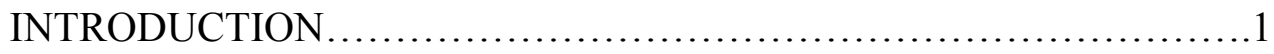

CHAPTER 2 .................................................................7

METHODOLOGY..........................................

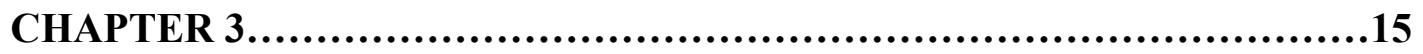

RESULTS AND DISCUSSION.................................... 15

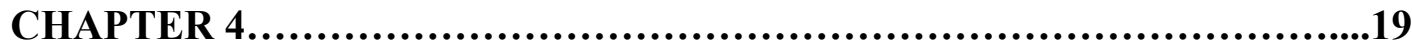

CONCLUSION ...................................................... 19

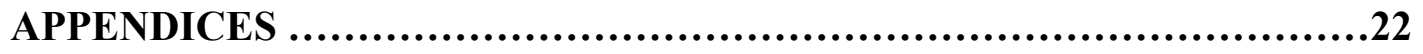

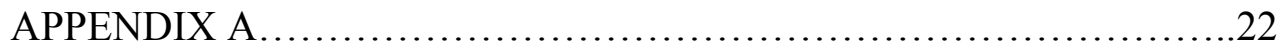

APPENDIX B................................................25

BIBLIOGRAPHY .............................................................38 


\section{LIST OF TABLES}

TABLE

PAGE

Table 1. Group 1's fabric structure, air permeability, total linearity error, linearity error between 0 and $0.958 \mathrm{kPa}$, and linearity error between 1.44 and $3.83 \mathrm{kPa} \ldots \ldots \ldots . .16$

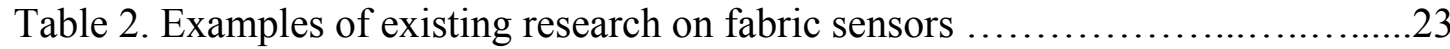

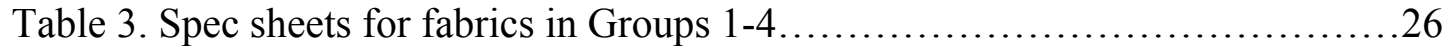

Table 4. Sensitivity for fabrics in Groups $1-4$ at $0.479 \mathrm{kPa}$ and $3.83 \mathrm{kPa} \ldots \ldots \ldots \ldots . . .27$

Table 5. Linearity error for fabrics in Groups $1-4$ at ranges of $0-0.958 \mathrm{kPa}$ and $1.44-$

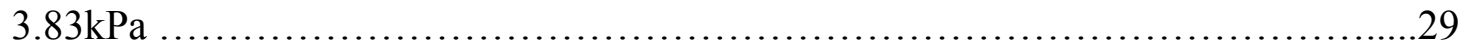

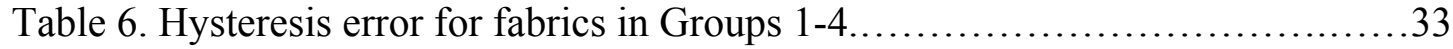

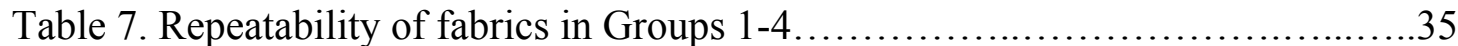




\section{LIST OF FIGURES}

FIGURE

PAGE

Figure 1. Diagram of a capacitor circuit and functional principle...................

Figure 2. Diagram of sensor setup. Figure not drawn to scale......................10

Figure 3. Diagram of discharge process. Figure not drawn to scale.................. 10

Figure 4. Diagram of weight application. Figure not drawn to scale................12

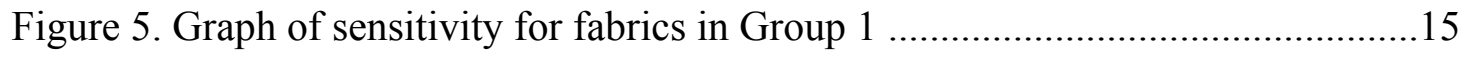

Figure 6. Graph of hysteresis error for fabrics in Group 1................................... 17

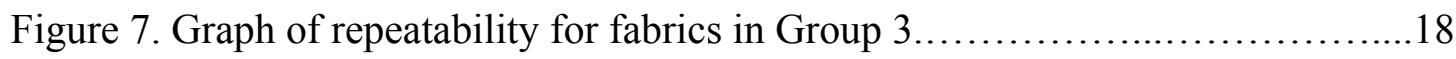

Figure 8. A capacitive pressure sensor made of a foam spacer sandwiched between a conductive yarn and a common electrode [5, Fig. 2]............................. 24

Figure 9. (a) Diagram of construction of a capacitive sensor belt for monitoring

respiration. (b) Completed belt sensor. [31, Fig. 2.] ...........................24

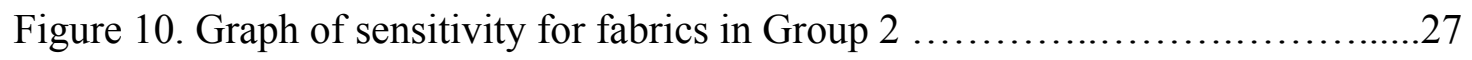

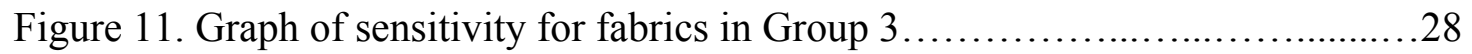

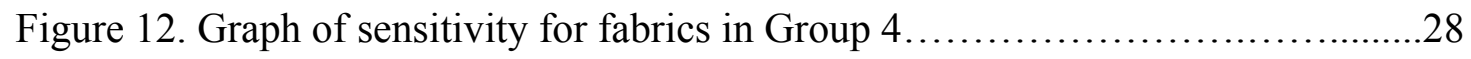

Figure 13. Graph of linearity for fabrics in Group $1(0-0.958 \mathrm{kPa}) \ldots \ldots \ldots \ldots \ldots \ldots . . .29$

Figure 14. Graph of linearity for fabrics in Group $1(1.44-3.83 \mathrm{kPa}) \ldots \ldots \ldots \ldots \ldots \ldots . \ldots . \ldots . \ldots . \ldots$

Figure 15. Graph of linearity for fabrics in Group $2(0-0.958 \mathrm{kPa}) \ldots \ldots \ldots \ldots \ldots \ldots \ldots$

Figure 16. Graph of linearity for fabrics in Group $2(1.44-3.83 \mathrm{kPa}) \ldots \ldots \ldots \ldots \ldots \ldots \ldots . .31$

Figure 17. Graph of linearity for fabrics in Group $3(0-0.958 \mathrm{kPa}) \ldots \ldots \ldots \ldots \ldots \ldots . \ldots . \ldots . . . . .1$

Figure 18. Graph of linearity for fabrics in Group $3(1.44-3.83 \mathrm{kPa}) \ldots \ldots \ldots \ldots \ldots \ldots . \ldots 32$ 
Figure 19. Graph of linearity for fabrics in Group $4(0-0.958 \mathrm{kPa}) \ldots \ldots \ldots \ldots \ldots \ldots . \ldots 32$

Figure 20. Graph of linearity for fabrics in Group $4(1.44-3.83 \mathrm{kPa}) \ldots \ldots \ldots \ldots \ldots \ldots . . . .33$

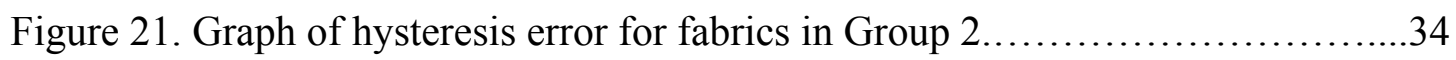

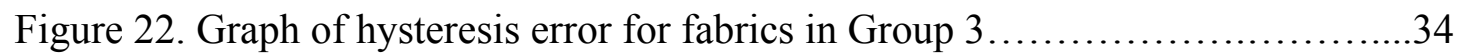

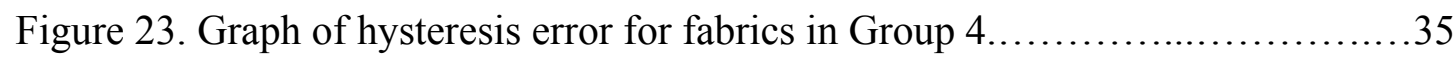

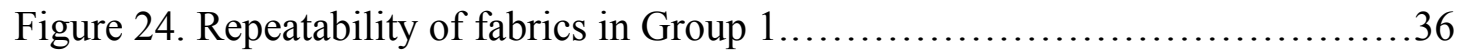

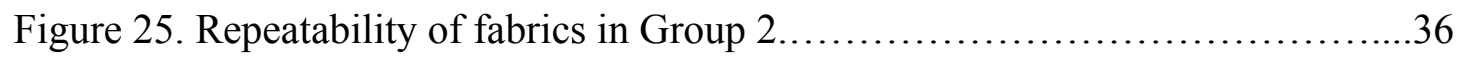

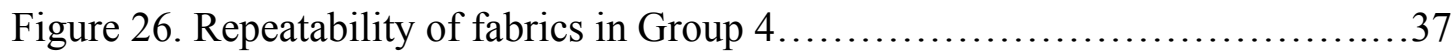




\section{CHAPTER 1}

\section{INTRODUCTION}

E-textiles are based on the incorporation of electronics, such as sensors, into garments. Innovative minds continue to find new uses for smart textiles in a wide variety of fields, including the medical, fashion, and gaming industries. Some of these sensors are based on a variation in capacitance as the textile is manipulated. Many studies using non-textile materials for the dielectric layer (spacer) of such capacitive sensors have shown that manipulating the porosity and the compressibility of the spacer can beneficially impact sensor output. However, the methods of modifying non-textile dielectric materials can be intricate, costly, and time-consuming [1], and it is preferable to integrate textile-based sensors into clothing for improved comfort, washability, and ease of integration. Textiles can effectively be used for the spacer of capacitive sensors, but their porosity and compressibility (and hence their capacitance) can change with the nature of fiber, yarn, and fabric. This study aims to investigate how constructional variations in the fabric used as a dielectric layer influence sensor output.

The e-textile market is currently valued at $\$ 100 \mathrm{~m}$ in annual wholesale revenue and is expected to reach $\$ 5$ b by 2027 [2]. As prices of manufacturing and electronics have dropped, the popularity of wearable technology has risen [3]. Both Google and Apple have increased their e-textile investments, and Google has even teamed up with Nike to produce athletic shoes that can track footsteps via Google Earth [3]. Wearable 
technology is also improving healthcare by way of telemedicine. A doctor can remotely monitor their patients' symptoms, cutting down on clinical visits, and providing doctors with a complete look at an individual's health [4]. When using sensors for continuous monitorization they should preferably be integrated directly into clothing because attachment is simple and more convenient for the user [5]. A table reviewing various implementations of textile sensors can be found in Appendix A.

Changes in response to an applied force can be measured by deviations in piezoelectric, piezoresistive, and capacitive values. Piezoelectric pressure sensors use piezoelectric materials, which create a voltage in response to mechanical deformation, whereas piezoresistive sensors use semiconductive materials that change resistivity [6, 7]. Capacitive sensors use nonconductive (dielectric) materials to store charge in conductive materials, and this charge varies in response to compression of the dielectric material [8]. Images of capacitive pressure sensors can be seen in Appendix A. Capacitive sensors are simpler, cheaper, more accurate, and more reliable than piezoelectric and piezoresistive $[9,10]$. Therefore, this study will focus on capacitive pressure sensors.

Capacitive pressure sensors usually consist of a dielectric material sandwiched between two conductive plates (electrodes). The spacer allows a charge to be stored in the conductive plates, and this ability to store charge is known as the capacitance. The capacitance is inversely correlated to the distance between the two electrodes. Therefore, when pressure is applied to the sensors, the distance between the two plates decreases, and the stored charge increases. Once calibrated, this change in capacitance 
can be used to determine the amount of pressure applied. See Figure 1 for a diagram of a capacitive pressure sensor. This is represented in the following formula [8]:

$$
C=\varepsilon_{0} \varepsilon_{r} \frac{A}{d}
$$

$\mathrm{C}$ is the capacitance of the sensor, $\varepsilon_{0}$ is the free space's dielectric constant, $\varepsilon_{r}$ is the spacer's dielectric constant, A is the overlapping surface area of the parallel plates, and $\mathrm{d}$ is the distance between those plates [8]. The dielectric constant, also known as relative permittivity, is the material's ability to store a charge [11]. When textiles are used, the type of fiber, surface area, and thickness of the material used for the dielectric spacer heavily impact the capacitance of the sensor, and therefore affect sensor output.

Figure 1. Diagram of a capacitor circuit and functional principle.

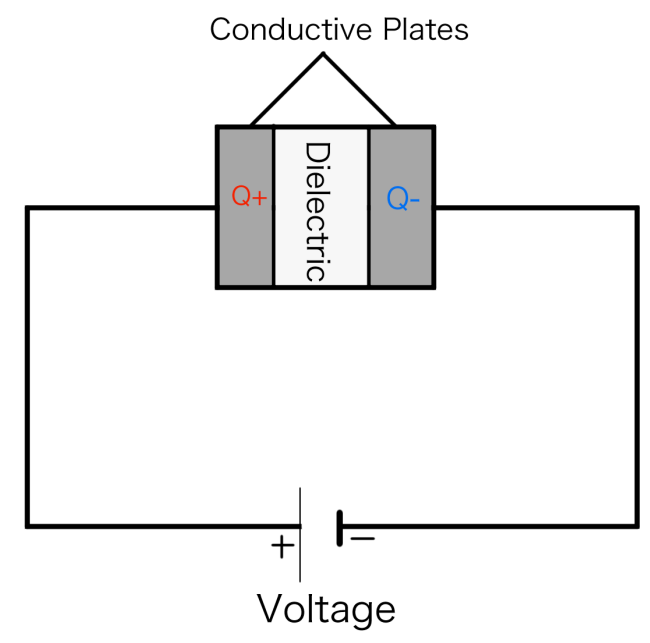

The dielectric material's deformation under compression strongly influences the sensor's pressure sensitivity. Sensitivity can be calculated by the following formula [8]: 


$$
S=\frac{\left(\Delta C / C_{0}\right)}{\Delta P}
$$

Where $\mathrm{S}$ is sensitivity, $\Delta \mathrm{P}$ is the change in pressure applied, $C_{0}$ is the baseline capacitance value when no force is used, and $\Delta C$ is the change in capacitance after the application of pressure [8].

The modification of non-textile dielectric structures controlling sensor output has been studied with promising results. The porosity of non-textile dielectric materials can be altered to improve sensitivity, with rough interfaces, micropillar arrays, or microscale pyramids [1]. Increased porosity improves sensor sensitivity by reducing stiffness and therefore increasing compressibility [12]. Additionally, the air pockets in the spacer act as a component of dielectric layer that can be compressed, even further improving sensitivity $[12,8,1]$. The resulting increase in sensitivity may not be consistent across all ranges of pressure. A study using capacitive pressure sensor insoles with a porous-silicone dielectric layer to continuously monitor the human gait found that at a low-pressure range, the air gaps were fully open, and therefore the sensors were most sensitive [8]. The capacitance was affected by both the change in distance within the micropores and the change in distance between the electrodes. As the applied pressure increased, the air gaps fully closed, and the capacitance was only affected by the change in distance between the two electrodes [8]. Since silicone is a rubbery material, it will likely maintain more compressibility than textile materials once all its micropores are closed.

While any dielectric material can be used for the spacer layer of a capacitive sensor, it is preferable for sensors used in wearable technology to be entirely 
composed of textiles as this improves comfort, ease of integration, and washability [5]. Images showing examples of textile capacitive pressure sensors can be seen in Appendix A. Much research has shown how factors, such as fabric construction method, weave density, yarn fineness, and filament fineness can impact a fabric's compressibility and porosity [13]. One study tested the compressional properties on woven fabrics with five different weave patterns and three different weft densities [14]. The thickness and recovery of these fabrics were measured at various pressures and were shown to depend on the weave pattern and the weft density. Investigating if these variations are significant enough to impact sensor output is the next logical step.

Any cyclic loading and unloading sequence can exhibit hysteresis, which is the discrepancy in measurement when a force is applied in increasing and decreasing values [15]. Since a fabric's speed of recovery can depend on its structure it is possible that construction method will impact hysteresis error. A study using a resistive textile strain sensor showed that hysteresis could result from friction and structural deviations within the fabric [16]. Similar distortions might occur from the application of pressure.

When all other aspects of fabrication are kept constant, variations in yarn construction impacts air permeability. The amount of twist in the yarn, the size of the yarns, the type of yarn structure, and fiber length all play a role [17]. For a given fabric count and yarn count, using yarns with a higher twist per inch (TPI) increases air permeability because it increases the gaps between yarns [18]. A yarn's texture impacts its volume, and thus textured yarns have a higher permeability than flat yarns [19]. This additional volume created by textured yarns can also increase 
compressibility [20]. Fiber length also measurably impacts air permeability. Yarns composed of staple fibers are hairy and must be spun to keep the fibers together. This hairiness can cover the gaps in-between yarns, thus disrupting air-flow compared to fabrics of the same structure composed with filament yarns [21].

Along with hysteresis, structural variations have the potential to impact sensitivity, range, linearity, and repeatability of the textile-based capacitive pressure sensors. Sensitivity is the smallest detectable amount of change in pressure. Range is the minimum and maximum detectable pressure values. Linearity error is the degree to which the actual sensor output curve varies from its line of best fit. Linearity error helps to show the predictability of the sensor and helps to break down the full range of a sensor into smaller, more functional ranges for practical uses. Repeatability is the sensor's ability to produce consistent results over the span of multiple trials.

This study serves as a preliminary study of the relationship between textile structure and variations in sensitivity, range, hysteresis, linearity, and repeatability of the textile dielectric layer of a capacitive pressure sensor. Possible trends between sensor output and air permeability will be examined. 


\section{CHAPTER 2}

\section{METHODOLOGY}

Materials:

-Two 2x102x102mm stainless steel plates

-BCP Double Sided Adhesive Conductive Tape

$-102 \times 102 \mathrm{~mm}$ plastic square

-Container (279x114x114mm)

-Assorted Polyester, Nylon, and Acrylic Fabrics

-Acetone

$-90 \%$ Formic Acid

-Dimethylformamide (DMF)

Equipment:

-FX 3300 Air Permeability Tester (TEXTEST)

-Capacitor discharge pen

-Elenco CM1555 Digital Capacitance Meter

-Thickness Gage

-Thread counter microscope

-Conditioning racks

-King Universal Manual Sample Cutter 
Fiber Identification:

For this experiment, the spacer materials were only synthetic fibers (specifically polyester, nylon, and acrylic) as they tend to have lower moisture regain and therefore are less impacted by humidity. Mohawk Fabrics provided three polyester knits and the University of Rhode Island's Textile Science Lab provided the other 22 fabrics. The 25 fabrics were assigned a number for the convenience of the researcher. Fiber identification was performed using the solubility and burn tests from AATCC Test Method 20 [22].

\section{Fabric Characterization:}

Thickness was assessed according to ASTM D1777-96 (2015): Standard Test Method for thickness of textile materials, via thickness gage [23]. The measurement was taken from ten different locations for each fabric. Since fiber content and thickness are known to affect functionality of the dielectric layer, fabrics of the same fiber content with similar thickness (within 50 microns) were selected for sensors.

The construction method of the chosen fabrics was determined visually. Further characterization testing was performed to determine fabric count, fabric weight, and fiber density in consideration of those who may continue this research. ASTM D3775-17e1, Standard Test Method for End (Warp) and Pick (Filling) Count [24] and ASTM D3774: Course Count of Knitted Fabrics [25] were used to determine count, and ASTM D3776: Fabric Weight [26] was used to determine weight. Normally, for ASTM D3776, a sample that runs the full width of the fabric is folded three times and cut with a cutting die and weighed. Due to limited supplies of fabric, only one circle 
was cut and weighed. That value was then multiplied by eight and converted to $g /$ $m^{2}$

Testing for air permeability:

Four specimens (a bare minimum of $153 \times 153 \mathrm{~mm}$ ) were cut from each fabric. Ideally the specimens would be broadly distributed across the length and width, along the diagonal of the fabric; however, they were cut in close proximity to each other due to limited supply of materials. The specimens were then placed on conditioning racks, for four hours in a room with $21+/-1^{\circ} \mathrm{C}$ and $65+/-2 \%$ relative humidity, in accordance with ASTM D1776: Standard Practice for Conditioning and Testing Textiles [27] ASTM D737-18: Standard Test Method for Air Permeability of Textile Fabrics was performed under the same temperature and humidity conditions [28]. The test apparatus was set to a pressure drop of $125 \mathrm{~Pa}$, in line with ASTM testing specifications. Density was determined by calculating the volume of that circle and dividing its weight by its volume.

\section{Sensor construction:}

The chosen fabrics were cut to $108 \times 108 \mathrm{~mm}$. These textile samples were sandwiched between two 2x102x102mm stainless steel plates. Metal plates are rigid and stable and will maintain a constant surface area, which reduces error when performing the experiments. One tab of conductive tape stabilized by cardboard was attached to each metal plate as connections for the sensors. The same two plates were used throughout. This set up can be seen in figure 2. A discharger was applied to the 
metal plates between trials to discharge any remaining stored charge. This process can be seen in figure 3 .

Figure 2. Diagram of sensor setup. Figure not drawn to scale.

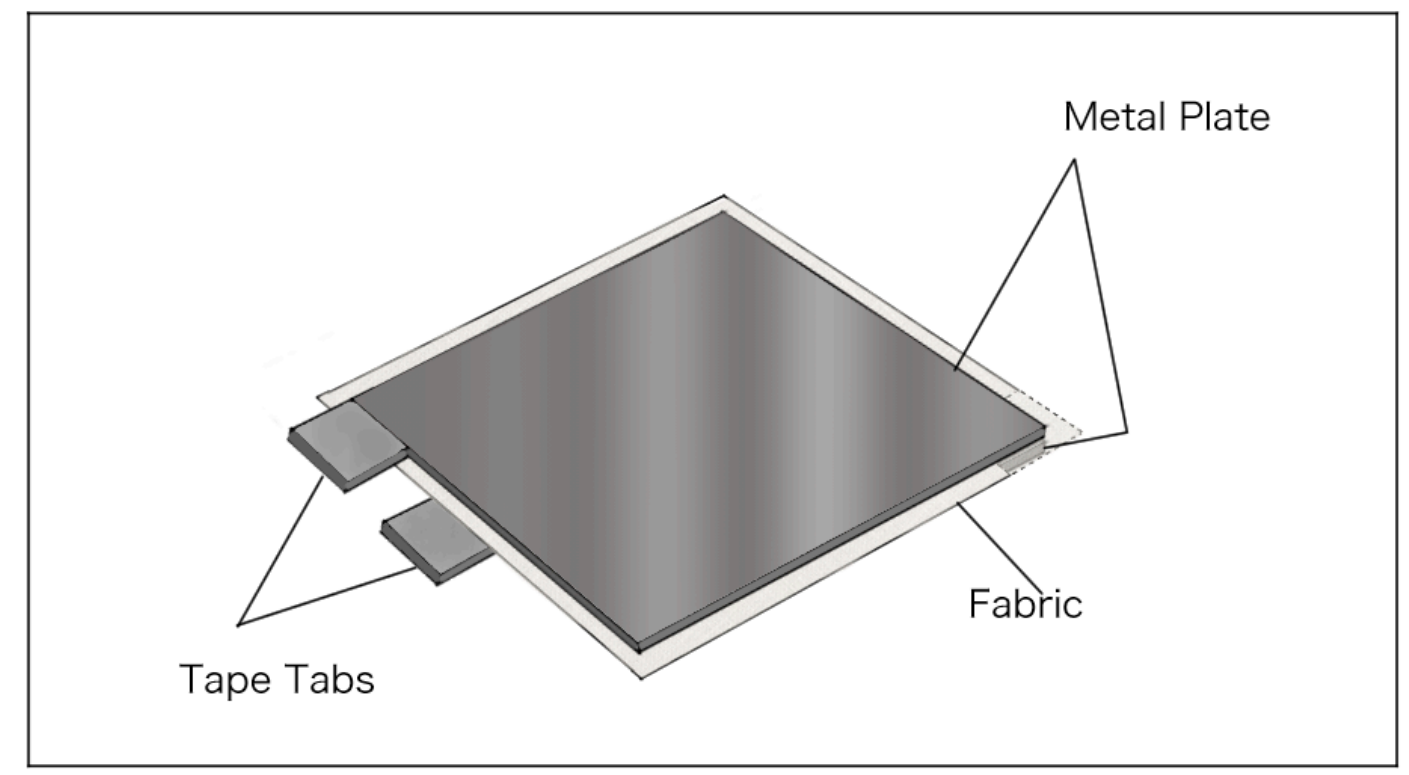

Figure 3. Diagram of discharge process. Figure not drawn to scale.

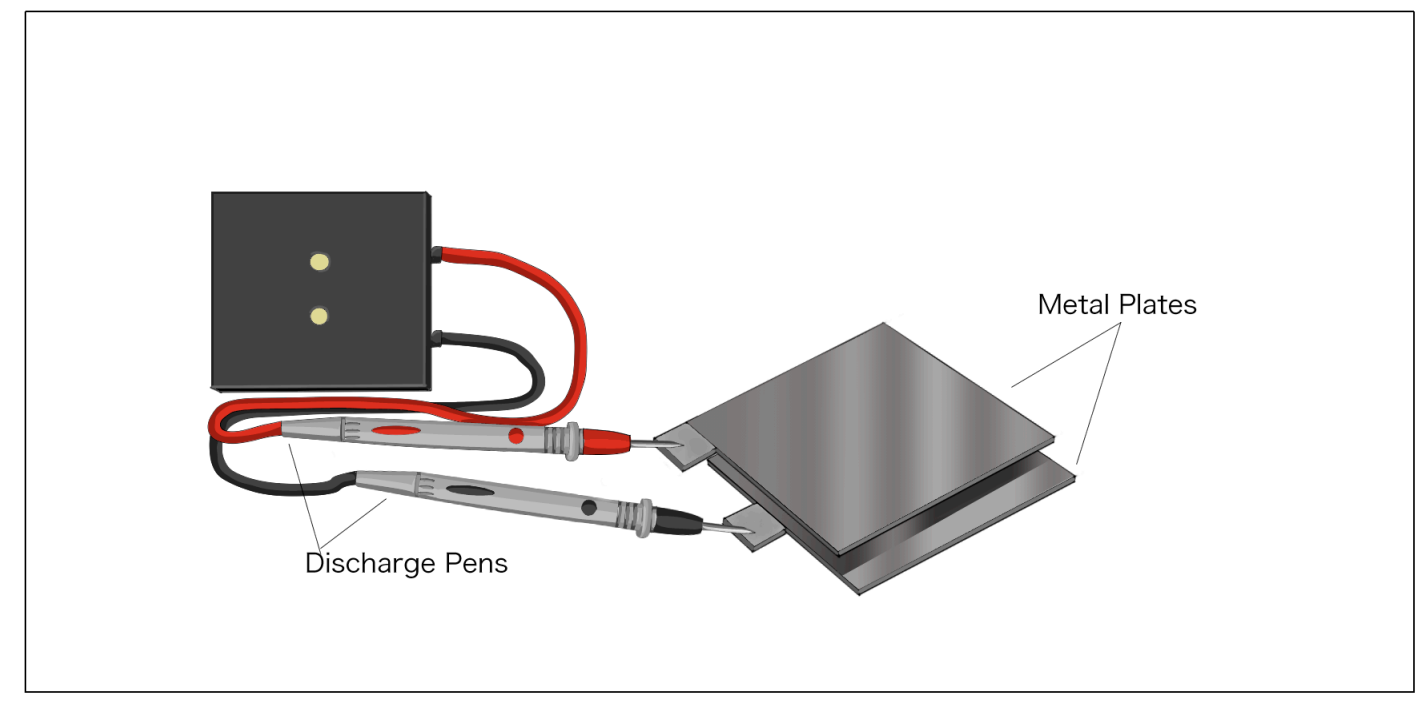




\section{Preliminary testing:}

Test parameters were determined in preliminary testing in which only fabrics with the same fiber content and a similar thickness were compared to be certain that any differences in sensor output resulted from textile structural variation. A spec sheet for these fabrics can be found in Appendix B.

Force was applied via a plastic container placed on top of a plastic square with the same dimensions as the metal plates $(102 \times 102 \mathrm{~mm})$. After constructing the sensor, both tabs were attached to the capacitance meter. Initially, weight was added by pouring water in $500 \mathrm{~g}$ increments in one minute until the load reached $2500 \mathrm{~g}$. During the preliminary testing process, the researcher concluded that water would be too difficult to use and opted to switch for 500g sandbags. The weight range was changed to $500 \mathrm{~g}-4000 \mathrm{~g}$ in order to be more informative when comparing changes in sensitivity. The capacitance reading stabilized within 20 seconds or less for each fabric, so a time interval of 30 seconds was used for subsequent testing. This process can be seen in figure 4. 
Figure 4. Diagram of weight application. Figure not drawn to scale.

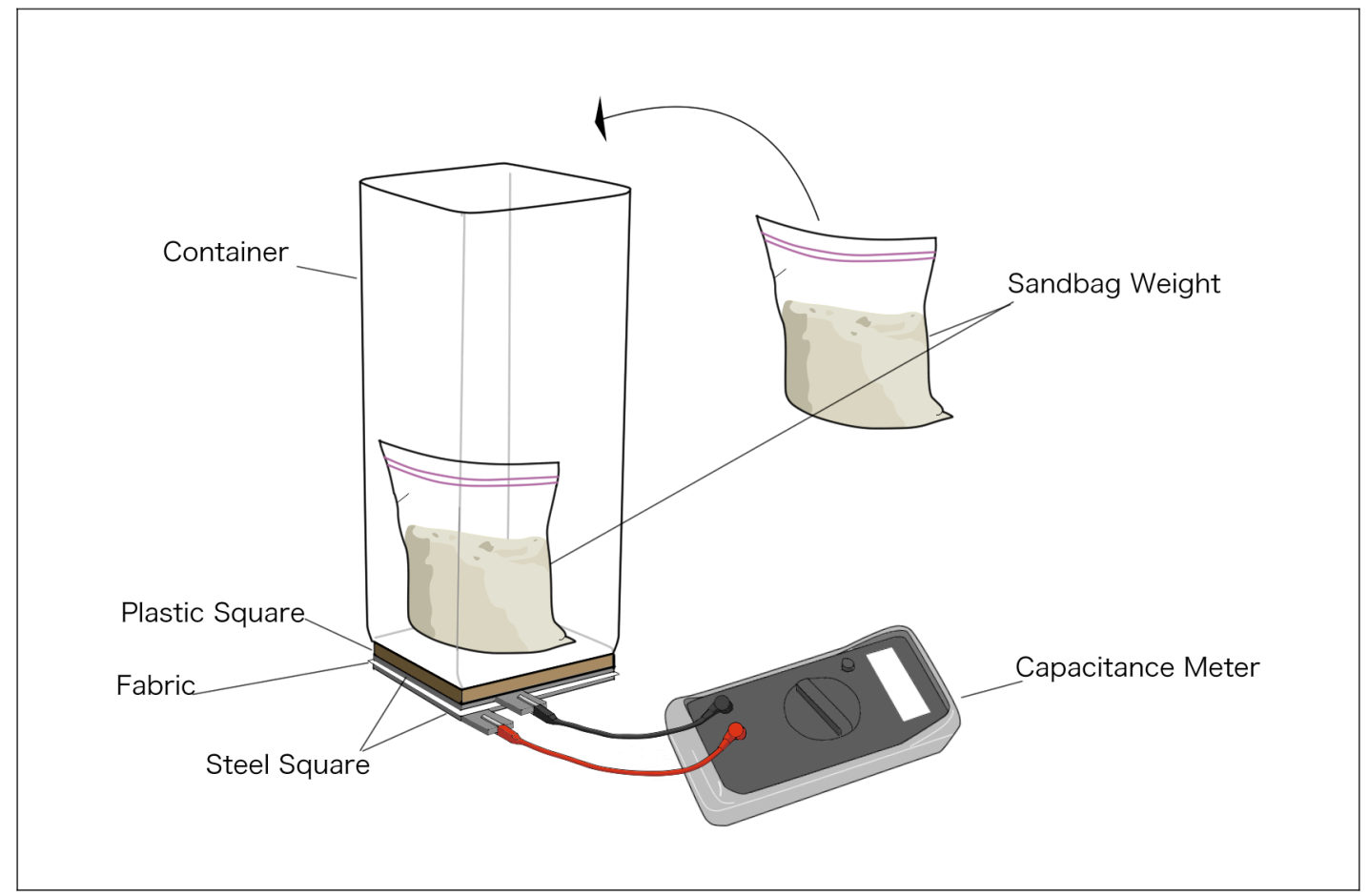

Sensor Testing:

Six trials were run for each of the 12 fabrics selected. Weight was added in $500 \mathrm{~g}(0.479 \mathrm{kPa})$ increments, every 30 seconds, until the maximum load of $4000 \mathrm{~g}$ $(3.83 \mathrm{kPa})$ was reached. Then weight was removed in $500 \mathrm{~g}$ increments, every 30 seconds, until the load was down to $0 \mathrm{~g}$. Hysteresis error was calculated from the loading and unloading data. Sensitivity, linearity, and repeatability were calculated from the loading data.

Hysteresis Error:

The data from the six trials was averaged and then the following formula was used to calculate hysteresis error [29]: 


$$
\delta \mathrm{H}=\frac{\Delta \mathrm{H}_{\max }}{Y} \times 100 \%
$$

Where $\delta \mathrm{H}$ is hysteresis, $\Delta \mathrm{H}_{\max }$ is the maximum difference between loading and unloading, and $\mathrm{Y}$ is the full-scale output of the sensor.

\section{Sensitivity:}

The following formula, previously referenced on pg. (3), was used to calculate sensitivity between $0-500 \mathrm{~g}(0-0.479 \mathrm{kPa})$ and between $3500-4000 \mathrm{~g}(3.35-3.83 \mathrm{kPa})$ :

$$
S=\frac{\left(\Delta C / C_{0}\right)}{\Delta P}
$$

\section{Linearity Error:}

For linearity, the loading data was broken into two sections, 0-1000g (0$0.958 \mathrm{kPa})$ and $1500-4000 \mathrm{~g}(1.44-3.83 \mathrm{kPa})$ since the error is typically calculated from the most linear portion. The data was graphed and the line of best fit was determined. The error was then calculated using the following formula [29]:

$$
\delta_{L}=\frac{\Delta Y_{\max }}{Y} \times 100 \%
$$

Where $\delta_{L}$ is linearity, $\Delta Y_{\max }$ is the maximum deviation between the capacitance curve and the line of best fit, and $\mathrm{Y}$ is the full-scale output. 
Repeatability:

The standard deviation for each weight increment was calculated from all six trials. The mean of the standard deviations for all nine weight increments served as the repeatability value. 


\section{CHAPTER 3}

\section{RESULTS AND DISCUSSION}

Figure 5. Graph of sensitivity for fabrics in Group 1.

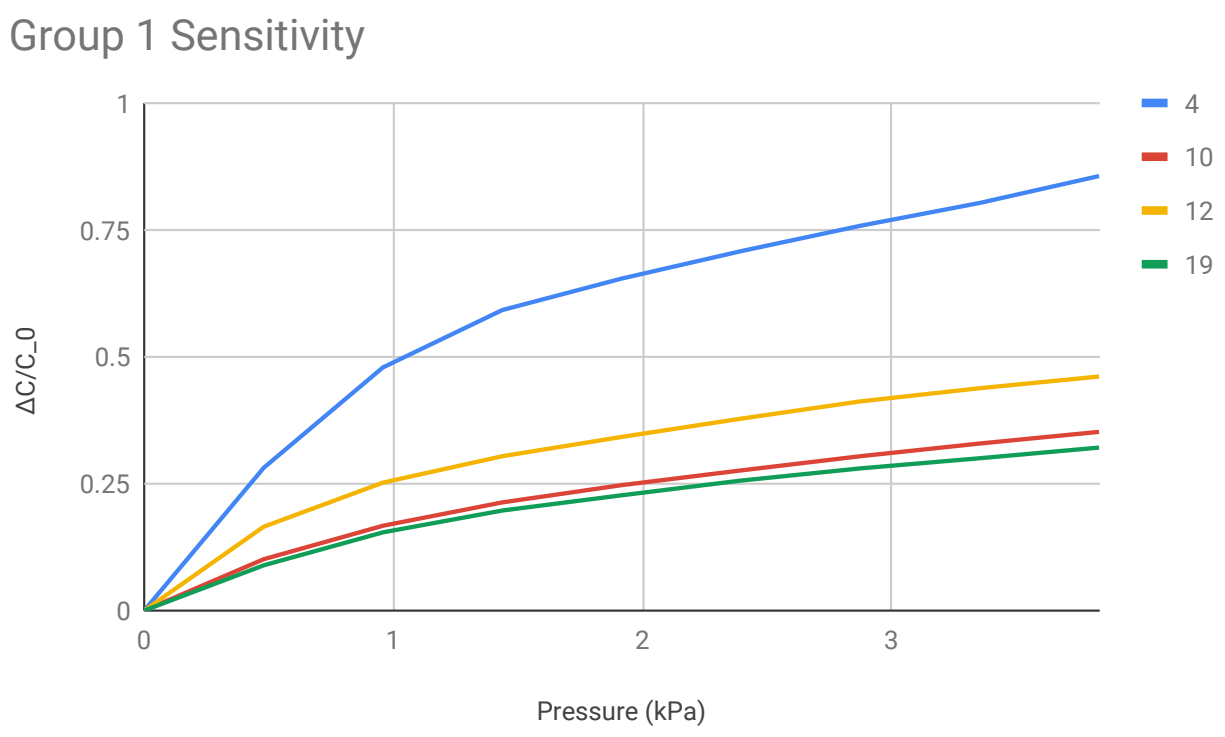

Group 1's sensitivity results are shown above to represent the sensitivity variations seen amongst the different groups. Fabric 10 had an air permeability value of $269 \mathrm{cfm}$, more than twice that of Fabric 12's air permeability of $121 \mathrm{cfm}$. However, as seen in the graph above, Fabric 12 is notably more sensitive than Fabric 10 . These results cannot be explained by the minimal differences in thickness between the fabrics, since Fabric 12 is also thicker than Fabric 10. These results indicate that there must be other structural parameters, beyond air permeability, impacting sensitivity. There was no consistent trend between air permeability and sensitivity in groups 2,3 , or 4, although the results also indicated that structural variation does have an impact. 
Table 1. Group 1's fabric structure, air permeability, total linearity error, linearity error between 0 and $0.958 \mathrm{kPa}$, and linearity error between 1.44 and $3.83 \mathrm{kPa}$.

\begin{tabular}{|c|c|c|c|c|c|}
\hline $\begin{array}{c}\text { Linearity } \\
\text { error }\end{array}$ & & & & & \\
\hline Group 1 & & & & & \\
\hline Fabric \# & Structure & $\begin{array}{c}\text { Air permeability } \\
\text { (cfm) }\end{array}$ & $\begin{array}{c}\text { total } \\
\text { error }\end{array}$ & $\begin{array}{c}0- \\
0.958 \mathrm{kPa}\end{array}$ & $\begin{array}{c}1.44- \\
3.83 \mathrm{kPa}\end{array}$ \\
\hline 4 & $\begin{array}{c}\text { weft jersey } \\
\text { knit }\end{array}$ & 632 & $26.2 \%$ & $6.00 \%$ & $3.71 \%$ \\
\hline 10 & $\begin{array}{c}\text { warp tricot } \\
\text { knit }\end{array}$ & 269 & $18.7 \%$ & $8.19 \%$ & $3.87 \%$ \\
\hline 12 & plain weave & 121 & $25.2 \%$ & $11.0 \%$ & $7.64 \%$ \\
\hline 19 & twill weave & 8.93 & $17.5 \%$ & $4.79 \%$ & $4.63 \%$ \\
\hline
\end{tabular}

Observing the linearity error further illustrates how various structure parameters beyond air permeability are affecting sensor output. In studies using non-textile dielectrics with added porosity, when the air pockets close, there is a decrease in sensitivity, which would in turn increase linearity error [8]. Looking at the relationship between air permeability and overall linearity error in Group 1, one can see that there is not a direct correlation between the two. Fabric 10 has air permeability of $269 \mathrm{cfm}$ and an overall linearity error of $18.7 \%$. Fabric 12 has air permeability of $121 \mathrm{cfm}$ and yet has a considerably higher linearity error of $25.2 \%$. This could be indicating that variations in fabric and yarn structure are causing the air pockets to compress at different rates. 
Figure 6. Graph of hysteresis error for fabrics in Group 1.

\section{Group 1 Hysteresis}

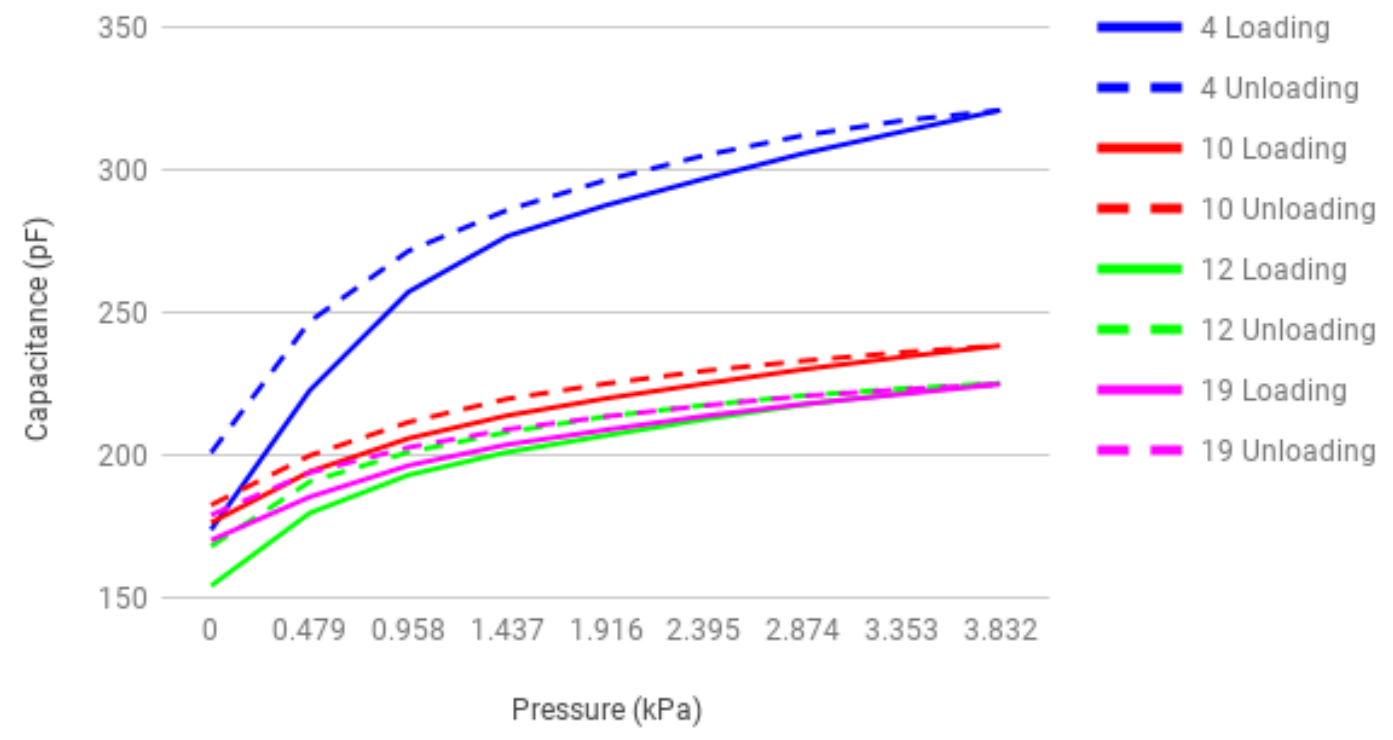

There was no clear pattern between hysteresis error and air permeability. Studies show that types of knit or woven patterns and variations in fabric count have an impact on compression recovery [14]. Although there were not enough controls in the construction parameters in this study to determine how they impact hysteresis error, the results do show distinct differences between fabrics within the same groups. 
Figure 7. Graph of repeatability for fabrics in Group 3.

\section{Group 3 Repeatability}

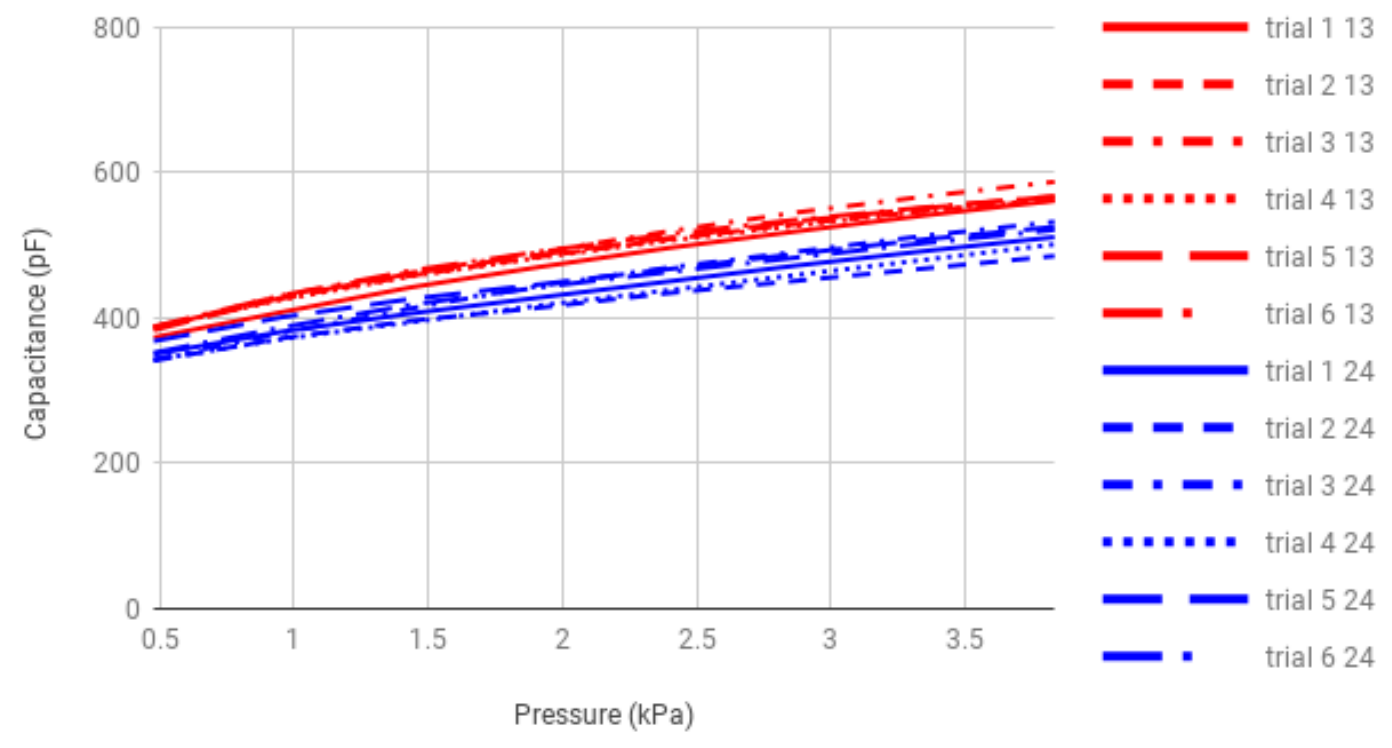

Repeatability also seemed to vary between within each group, without an obvious link to air permeability. User error may account for some of the discrepancies, however, structural components likely play a large role as well.

While performing characterization testing, it was discovered that Fabric 2 and 3 are likely the same fabric from different bolts. Although the inconsistencies in their structures were minimal, there were noticeable differences in sensitivity and linearity at a lower pressure range, as well as in repeatability. Further research should be done to see if small variations in manufacturing can cause significant discrepancies in sensor output as this can be a concern when mass producing textile-based sensors.

The rest of the tables and graphs can be found in Appendix B. 


\section{CHAPTER 4}

\section{CONCLUSION}

Evaluation of the sensors for sensitivity, linearity, hysteresis, and repeatability shows that structural parameters of the textile dielectric layer can impact sensor output although; air permeability is not a reliable predicting factor. While a higher air permeability value would indicate greater volumes of air pockets to act as an additional dielectric layer, it does not determine the quantity of air pockets or how the pockets will compress under a given pressure. This study could not definitively show a connection between sensor output and air permeability. However, it does support the theory that structural variations in fabric can impact output.

The fact that there was no consistent trend between sensor output and fabric structure is an important finding in itself. These results do not necessarily dismiss the role of knit and weave patterns in capacitive pressure sensors, but rather show that many other elements of fabric are also relevant. This is significant in terms of sensor applications because it means that there is potential to combine different fabric construction qualities in order to pick a material that is ideal for the end-use of the etextile while still meeting the data collection needs of the sensor.

These findings are very promising and suggest that additional research would be beneficial for the world of wearable technology. Fabric structure can vary in many capacities, such as fiber length, turns per inch in yarn, fineness of yarn, thread count, weave or knit pattern, and more. Further studies with control over these structural 
parameters would be necessary to determine which factors are most influential and what specific impact they have on sensor output. For example, qualities such density and weight may alter how air pockets compress, which could in turn impact linearity. Such studies could offer clarity when choosing textiles that meet both the needs of the sensor and the needs of the garments that the sensors are being integrated into.

One recommended area of study would be fabric compressibility in relation to range, sensitivity, and linearity. In non-textile based pressure sensors, using a more compressible dielectric material can improve sensor range and sensitivity, so it is likely that fabrics would follow a similar trend. Additionally, possible trends between compression recovery and hysteresis error and repeatability could be explored. Textiles with poor compression recovery may have a greater lag between increasing and decreasing loads so it is possible that compression recovery could be a predictor for hysteresis error. Furthermore, testing compressibility could potentially offer more understanding of the role of air permeability. Fabrics with varying air permeability and similar compressibility and fabrics with similar air permeability and varying compressibility could both be compared to see if either factor has greater impact on sensor output.

Along with testing for influential fabric qualities, it would be useful to do additional testing for sensor proficiency. The sensors can be laundered and subjected to other wearable simulations before being tested to decide which materials would function best for different uses. The sensors could also be put through repeated trials to explore longevity. Other recommended tests include testing for full range and 
repeatedly adding and taking away the same amount of weight in order to see how the fabric responds in different applications.

This research offers a preliminary look at the potential for manipulating sensor output of capacitive pressure sensors via variations in structural parameters of a textile-based dielectric layer. The results show that differences in structure do impact sensor output. Further exploration is necessary to determine which aspects of structure alter sensor output. 
APPENDIX A

Examples of Sensors 
Table 2. Examples of existing research on fabric sensors

\begin{tabular}{|c|c|c|c|c|c|}
\hline Reference & Year & $\begin{array}{l}\text { Functional } \\
\text { Principle }\end{array}$ & Matrix/Single & Materials & Usage \\
\hline [30] & 2018 & Piezo-resistive & $\begin{array}{l}\text { Single } \\
(2.5 \times 3.5 \mathrm{~cm})\end{array}$ & $\begin{array}{l}\text { Conductive Shieldex } \\
\text { NoraDell woven fabric } \\
\text { sheets, Low Density } \\
\text { Polyethylene sheet }\end{array}$ & $\begin{array}{l}\text { Finger tips of } \\
\text { gloves for } \\
\text { measuring } \\
\text { pressure of grip }\end{array}$ \\
\hline [5] & 2010 & Capacitive & $\begin{array}{l}\text { Matrix } 240 \\
\text { elements } \\
(430 \times 450 \mathrm{~mm})\end{array}$ & $\begin{array}{l}\text { Silver coated woven } \\
\text { textiles, polyester foam } \\
\text { spacer }\end{array}$ & $\begin{array}{l}\text { Seat for Posture } \\
\text { Monitoring }\end{array}$ \\
\hline [12] & 2018 & Capacitive & $\begin{array}{l}\text { Single } \\
(15 \mathrm{x} 15 \mathrm{~mm})\end{array}$ & $\begin{array}{l}\text { Conductive knit fabric, } \\
\text { microporous silicone } \\
\text { spacer }\end{array}$ & $\begin{array}{l}\text { Gloves for } \\
\text { monitoring } \\
\text { grasp, and } \\
\text { potential soft } \\
\text { wearable robotic } \\
\text { uses }\end{array}$ \\
\hline [16] & 2006 & Piezo-resistive & Matrix & $\begin{array}{l}\text { Polyacrylonitrile yarn } \\
\text { knitted into a fabric }\end{array}$ & $\begin{array}{l}\text { Possible uses } \\
\text { include: } \\
\text { monitoring body } \\
\text { movement, pulse, } \\
\text { and blood } \\
\text { pressure as well } \\
\text { as industry strain } \\
\text { gauges for planes }\end{array}$ \\
\hline [31] & 2014 & Capacitive & $\begin{array}{l}\text { Single } \\
(830 \times 38.6 \mathrm{~mm})\end{array}$ & $\begin{array}{l}\text { Polyester fabric plated } \\
\text { with nickel and copper, } \\
\text { polyester fusible woven } \\
\text { interlining }\end{array}$ & $\begin{array}{l}\text { Monitoring } \\
\text { respiration }\end{array}$ \\
\hline [32] & 2016 & Piezo-resistive & $\begin{array}{l}\text { Matrix } 32 \times 32 \\
\text { sensing } \\
\text { elements } \\
(39 \times 39 \mathrm{~cm} \\
\text { active area }) \\
\end{array}$ & $\begin{array}{l}\text { Cotton fabric, silver } \\
\text { coated conductive yarns }\end{array}$ & $\begin{array}{l}\text { Telemedicine: } \\
\text { remotely monitor } \\
\text { patients with } \\
\text { limited mobility }\end{array}$ \\
\hline [33] & 2013 & Capacitive & $\mathrm{N} / \mathrm{A}$ & $\begin{array}{l}\text { Hollow woven } \\
\text { conductive fibers }\end{array}$ & $\begin{array}{l}\text { Pressure sensor } \\
\text { on mattress to } \\
\text { monitor ulcer } \\
\text { patients. Shoe } \\
\text { insoles to } \\
\text { monitor gait } \\
\text { analysis and } \\
\text { athletes for } \\
\text { training purposes }\end{array}$ \\
\hline
\end{tabular}


Figure 8. A capacitive pressure sensor made of a foam spacer sandwiched between a conductive yarn and a common electrode [5, Fig. 2]. C 2010 IEEE

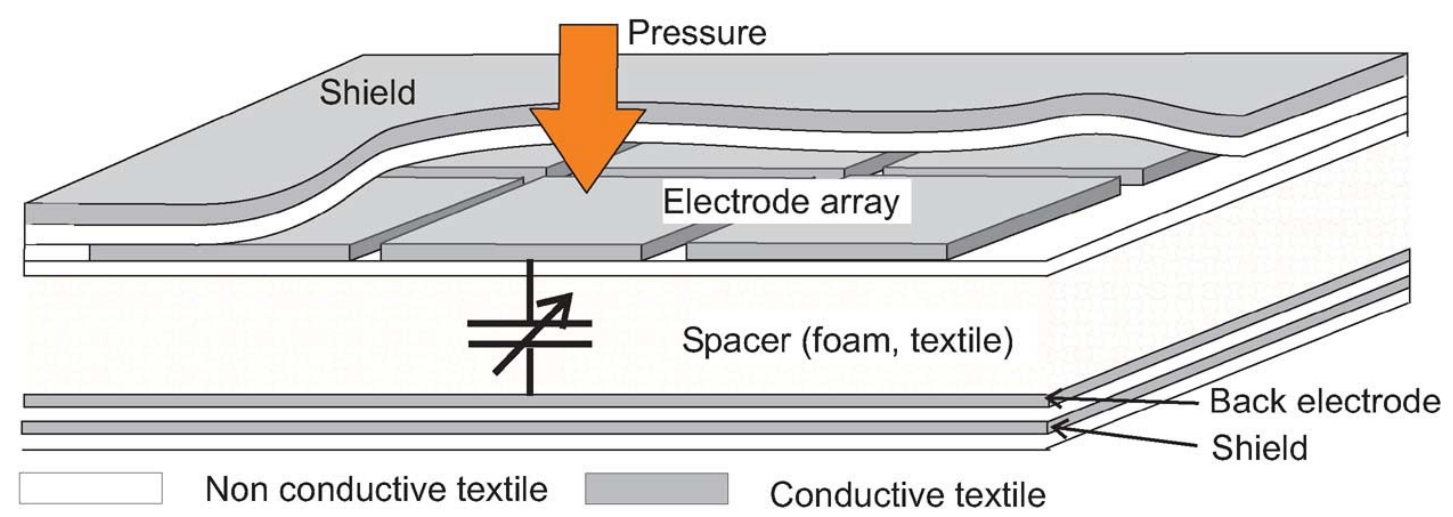

Figure 9. (a) Diagram of construction of a capacitive sensor belt for monitoring respiration. (b) Completed belt sensor. [31, Fig. 2.]. C2013 IEEE

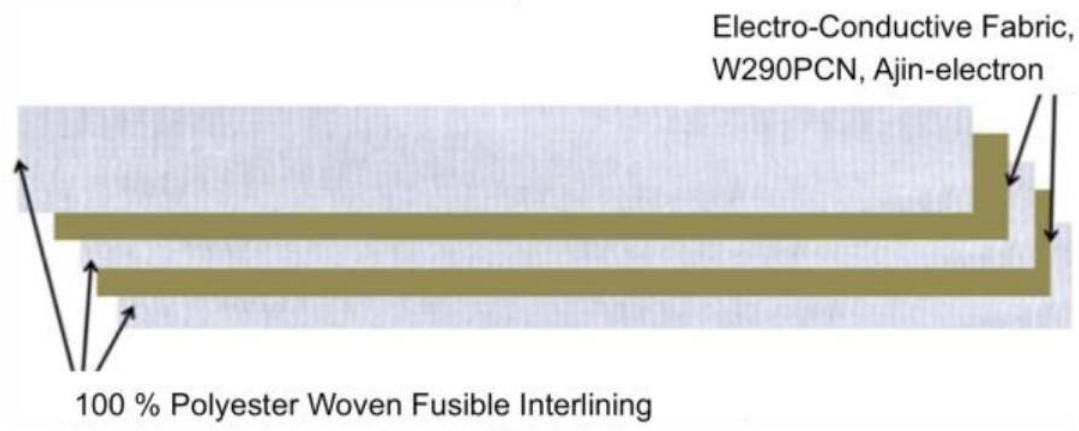

(a)

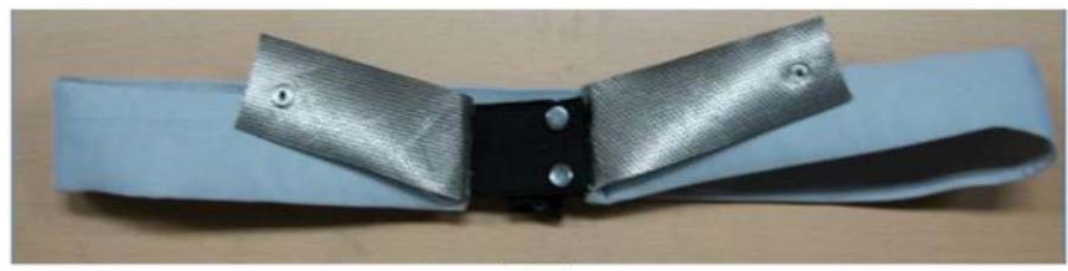

(b) 
APPENDIX B

Data 
Table 3. Spec sheets for fabrics in Groups 1-4.

\begin{tabular}{|c|c|c|c|c|c|c|}
\hline \multicolumn{7}{|l|}{$\begin{array}{l}\text { Group 1 } \\
\text { (polyester) }\end{array}$} \\
\hline Fabric \# & $\begin{array}{l}\text { thickness } \\
\text { (microns) }\end{array}$ & pattern & count & $\begin{array}{l}\text { weight } \\
\left(\mathrm{g} / \mathrm{m}^{2}\right)\end{array}$ & $\begin{array}{l}\text { Density } \\
\left(\mathrm{g} / \mathrm{cm}^{3}\right)\end{array}$ & $\begin{array}{l}\text { Air permeability } \\
\text { (cfm) }\end{array}$ \\
\hline 4 & 489.0 & \begin{tabular}{|l|} 
weft \\
jersey knit
\end{tabular} & $\begin{array}{l}28 \times 26 \\
(\mathrm{cxw})\end{array}$ & 160.0 & 0.3270 & 632.0 \\
\hline 10 & 459.0 & \begin{tabular}{|l} 
warp \\
tricot knit
\end{tabular} & $\begin{array}{l}40 \times 42 \\
(\mathrm{cxw})\end{array}$ & 200.0 & 0.4430 & 269.0 \\
\hline 12 & 478.0 & \begin{tabular}{|l} 
plain \\
weave
\end{tabular} & $\begin{array}{l}42 \times 33 \\
(w \times f)\end{array}$ & 180.0 & 0.3790 & 121.0 \\
\hline 19 & 465.0 & \begin{tabular}{|l} 
twill \\
weave
\end{tabular} & $\begin{array}{l}107 \times 86 \\
(w x f)\end{array}$ & 180.0 & 0.3940 & 8.930 \\
\hline \multicolumn{7}{|l|}{$\begin{array}{l}\text { Group } 2 \\
\text { (polyester) }\end{array}$} \\
\hline Fabric \# & $\begin{array}{l}\text { thickness } \\
\text { (microns) }\end{array}$ & pattern & count & $\begin{array}{l}\text { weight } \\
\left(\mathrm{g} / \mathrm{m}^{2}\right)\end{array}$ & $\begin{array}{l}\text { Density } \\
\left(\mathrm{g} / \mathrm{cm}^{3}\right)\end{array}$ & $\begin{array}{l}\text { Air permeability } \\
\text { (cfm) }\end{array}$ \\
\hline 9 & 249.0 & $\begin{array}{l}\text { warp } \\
\text { tricot knit }\end{array}$ & $\begin{array}{l}42 \times 35 \\
(\mathrm{c} \times w)\end{array}$ & 80.00 & 0.3130 & 977.0 \\
\hline 11 & 255.0 & \begin{tabular}{|l} 
warp \\
tricot knit
\end{tabular} & $\begin{array}{l}58 \times 47 \\
(\mathrm{cxw}) \\
\end{array}$ & 200.0 & 0.3940 & 541.0 \\
\hline 18 & 216.0 & \begin{tabular}{|l} 
plain \\
weave
\end{tabular} & $\begin{array}{l}51 \times 55 \\
(\mathrm{wxf})\end{array}$ & 70.00 & 0.3370 & 908.0 \\
\hline \multicolumn{7}{|l|}{$\begin{array}{l}\text { Group 3 } \\
\text { (nylon) }\end{array}$} \\
\hline Fabric \# & $\begin{array}{l}\text { thickness } \\
\text { (microns) }\end{array}$ & pattern & count & $\begin{array}{l}\text { weight } \\
\left(\mathrm{g} / \mathrm{m}^{2}\right)\end{array}$ & $\begin{array}{l}\text { Density } \\
\left(\mathrm{g} / \mathrm{cm}^{3}\right)\end{array}$ & $\begin{array}{l}\text { Air permeability } \\
\text { (cfm) }\end{array}$ \\
\hline 13 & 152.0 & $\begin{array}{l}\text { twill } \\
\text { weave }\end{array}$ & $\begin{array}{l}138 \times 89 \\
(w x f)\end{array}$ & 100.0 & 0.6350 & 6.570 \\
\hline 24 & 191.0 & \begin{tabular}{|l} 
plain \\
weave
\end{tabular} & $\begin{array}{l}63 \times 52 \\
(w \times f)\end{array}$ & 100.0 & 0.5320 & 26.50 \\
\hline \multicolumn{7}{|l|}{\begin{tabular}{|l|} 
Group 4 \\
(acrylic)
\end{tabular}} \\
\hline Fabric \# & $\begin{array}{l}\text { thickness } \\
\text { (microns) }\end{array}$ & pattern & count & $\begin{array}{l}\text { weight } \\
\left(\mathrm{g} / \mathrm{m}^{2}\right)\end{array}$ & $\begin{array}{l}\text { Density } \\
\left(\mathrm{g} / \mathrm{cm}^{3}\right)\end{array}$ & $\begin{array}{l}\text { Air permeability } \\
(\mathrm{cfm})\end{array}$ \\
\hline 2 & 434.0 & \begin{tabular}{|l|} 
plain \\
weave
\end{tabular} & $\begin{array}{l}48 \times 40 \\
(w x f)\end{array}$ & 140.0 & 0.3230 & 203.0 \\
\hline 3 & 417.0 & \begin{tabular}{|l} 
plain \\
weave
\end{tabular} & $\begin{array}{l}50 \times 40 \\
(\mathrm{wxf})\end{array}$ & 150.0 & 0.3480 & 146.0 \\
\hline 21 & 414.0 & $\begin{array}{l}\text { Crepe } \\
\text { weave }\end{array}$ & $\begin{array}{l}75 \times 60 \\
(w x f)\end{array}$ & 120.0 & 0.2950 & 157.0 \\
\hline
\end{tabular}


Table 4. Sensitivity for fabrics in Groups $1-4$ at $0.479 \mathrm{kPa}$ and $3.83 \mathrm{kPa}$.

\begin{tabular}{|c|c|c|c|c|c|c|c|c|c|c|c|}
\hline \multicolumn{3}{|c|}{ Group 1} & \multicolumn{3}{|c|}{ Group 2} & \multicolumn{3}{|c|}{ Group 3} & \multicolumn{3}{|c|}{ Group 4} \\
\hline \begin{tabular}{|l|} 
fabric \\
$\#$
\end{tabular} & $0.479 \mathrm{kPa}$ & $3.83 \mathrm{kPa}$ & \begin{tabular}{|l} 
fabric \\
$\#$
\end{tabular} & $0.479 \mathrm{kPa}$ & $3.83 \mathrm{kPa}$ & \begin{tabular}{|l} 
fabric \\
$\#$
\end{tabular} & $0.479 \mathrm{kPa}$ & $3.83 \mathrm{kPa}$ & $\begin{array}{l}\text { fabric } \\
\#\end{array}$ & $0.479 \mathrm{kPa}$ & $3.83 \mathrm{kPa}$ \\
\hline 4 & 0.587 & 0.0900 & 9 & 0.203 & 0.0590 & 13 & 0.223 & 0.100 & 2 & 0.517 & 0.0570 \\
\hline 10 & 0.211 & 0.0470 & 11 & 0.182 & 0.0530 & 24 & 0.194 & 0.0980 & 3 & 0.465 & 0.0550 \\
\hline 12 & 0.345 & 0.0470 & 18 & 0.237 & 0.0660 & & & & 21 & 0.272 & 0.0490 \\
\hline 19 & 0.187 & 0.0430 & & & & & & & & & \\
\hline
\end{tabular}

Figure 10. Graph of sensitivity for fabrics in Group 2.

Group 2 Sensitivity

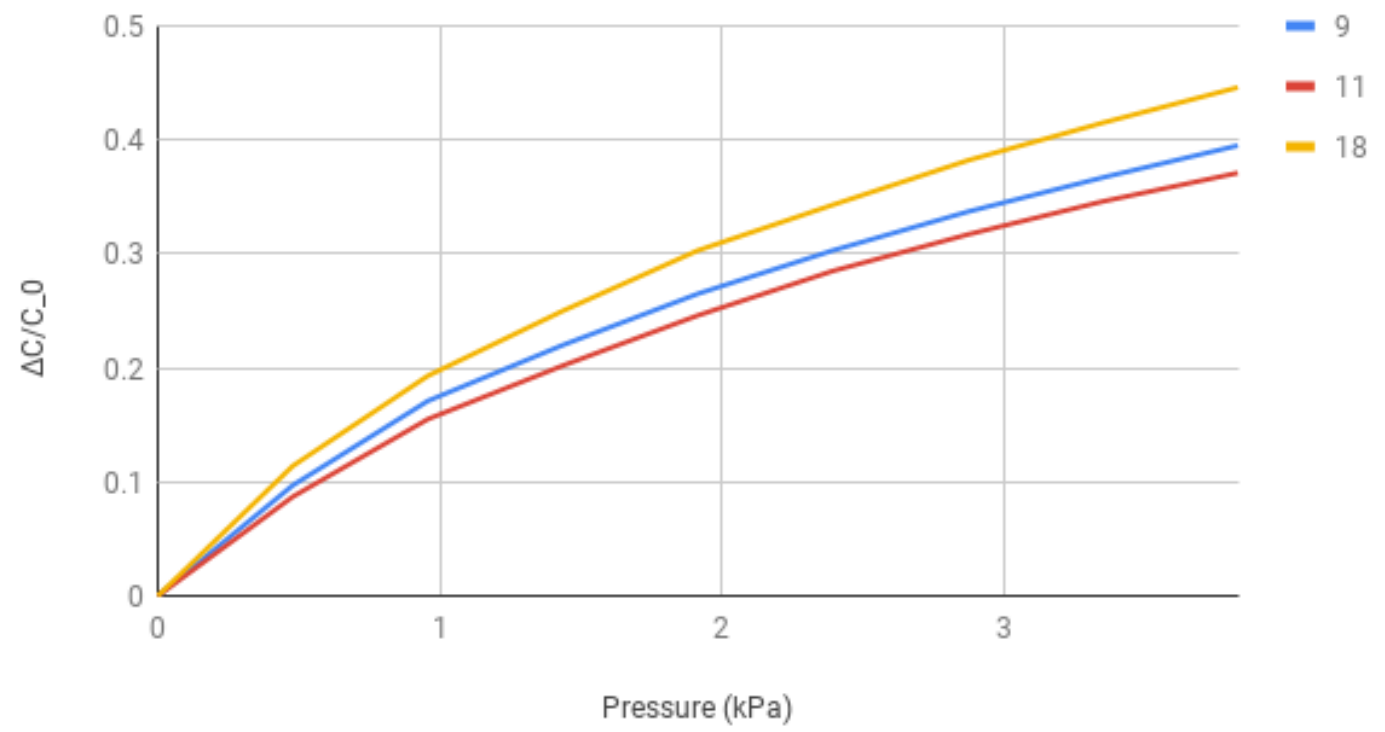


Figure 11. Graph of sensitivity for fabrics in Group 3.

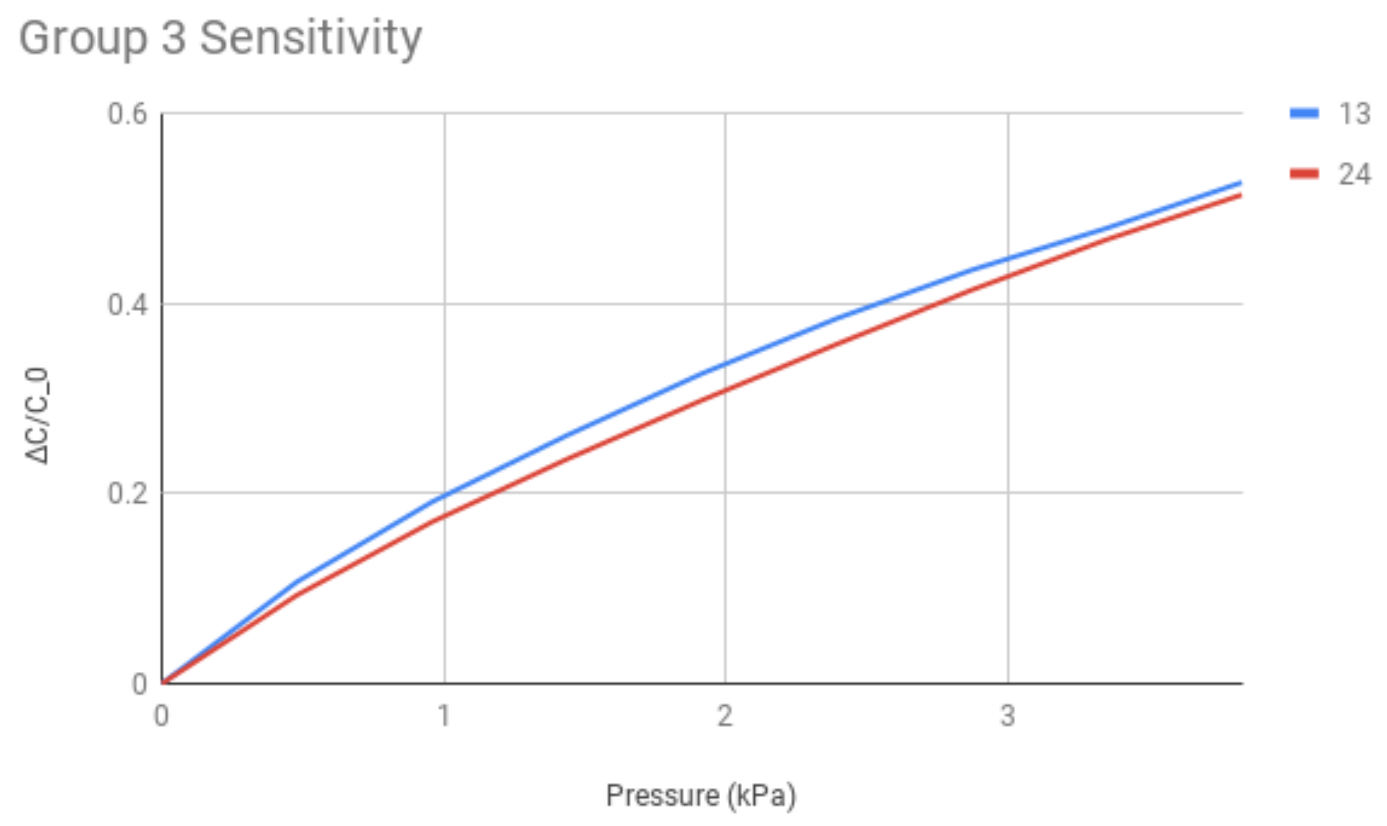

Figure 12. Graph of sensitivity for fabrics in Group 4.

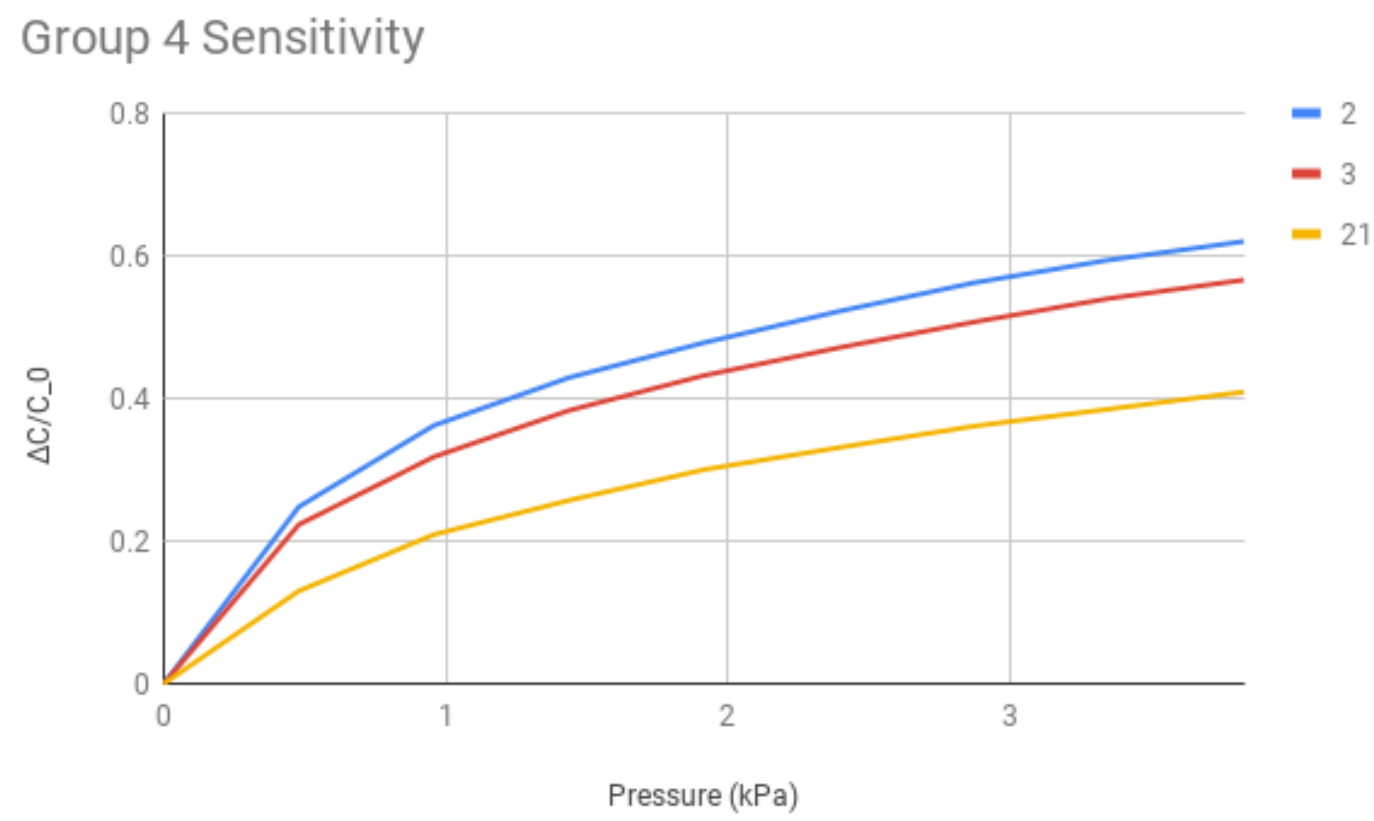


Table 5. Linearity error for fabrics in Groups $1-4$ at ranges of $0-0.958 \mathrm{kPa}$ and $1.44-$ $3.83 \mathrm{kPa}$

\begin{tabular}{|r|r|r|r|r|r|}
\hline Group 1 & & & Group 2 & & \\
\hline Fabric \# & $0-0.958 \mathrm{kPa}$ & $1.44-3.83 \mathrm{kPa}$ & Fabric \# & $0-0.958 \mathrm{kPa}$ & $1.44-3.83 \mathrm{kPa}$ \\
\hline 4 & $6.00 \%$ & $3.71 \%$ & 9 & $5.00 \%$ & $4.40 \%$ \\
\hline 10 & $8.19 \%$ & $3.87 \%$ & 11 & $4.27 \%$ & $6.00 \%$ \\
\hline 12 & $11.0 \%$ & $7.64 \%$ & 18 & $5.11 \%$ & $5.66 \%$ \\
\hline 19 & $4.79 \%$ & $4.63 \%$ & Group 4 & & \\
\hline Group 3 & & & Fabric \# & $0-0.958 \mathrm{kPa}$ & $1.44-3.83 \mathrm{kPa}$ \\
\hline Fabric \# & $0-0.958 \mathrm{kPa}$ & $1.44-3.83 \mathrm{kPa}$ & 2 & $12.3 \%$ & $4.92 \%$ \\
\hline 13 & $4.44 \%$ & $3.44 \%$ & 3 & $13.3 \%$ & $4.38 \%$ \\
\hline 24 & $3.50 \%$ & $2.19 \%$ & 21 & $9.19 \%$ & $5.46 \%$ \\
\hline
\end{tabular}

Figure 13. Graph of linearity for fabrics in Group $1(0-0.958 \mathrm{kPa})$.

\section{Linearity Group $1(0-.958 \mathrm{kPa})$}

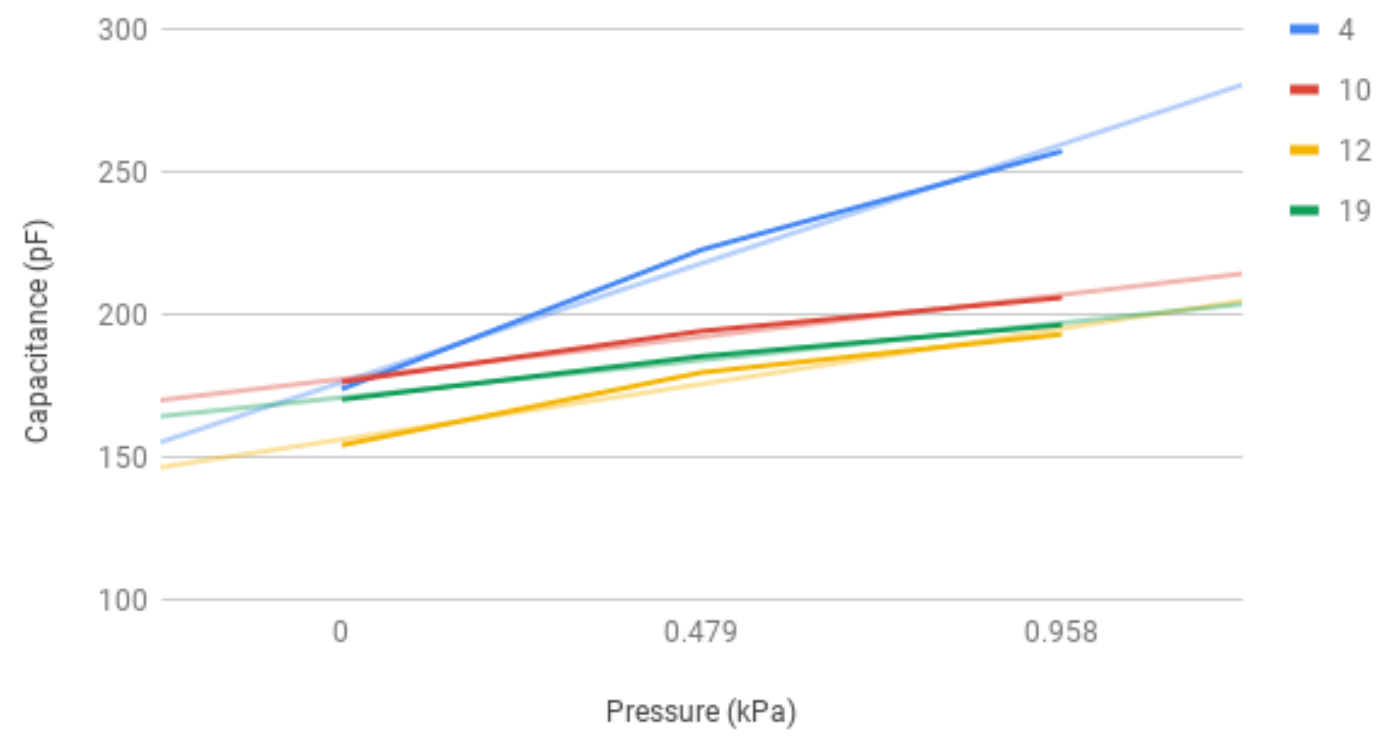


Figure 14. Graph of linearity for fabrics in Group 1 (1.44-3.83kPa).

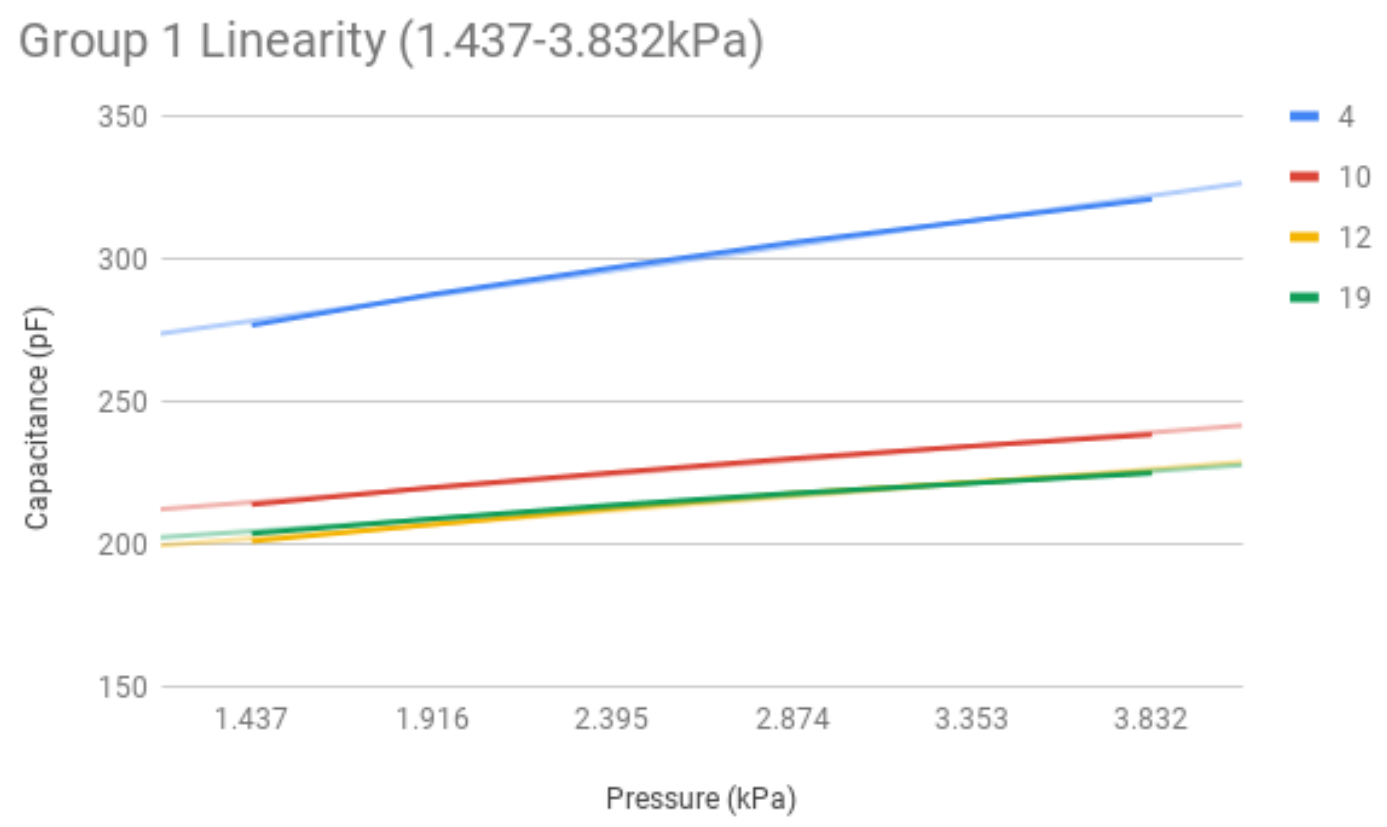

Figure 15. Graph of linearity for fabrics in Group 2 (0-0.958kPa).

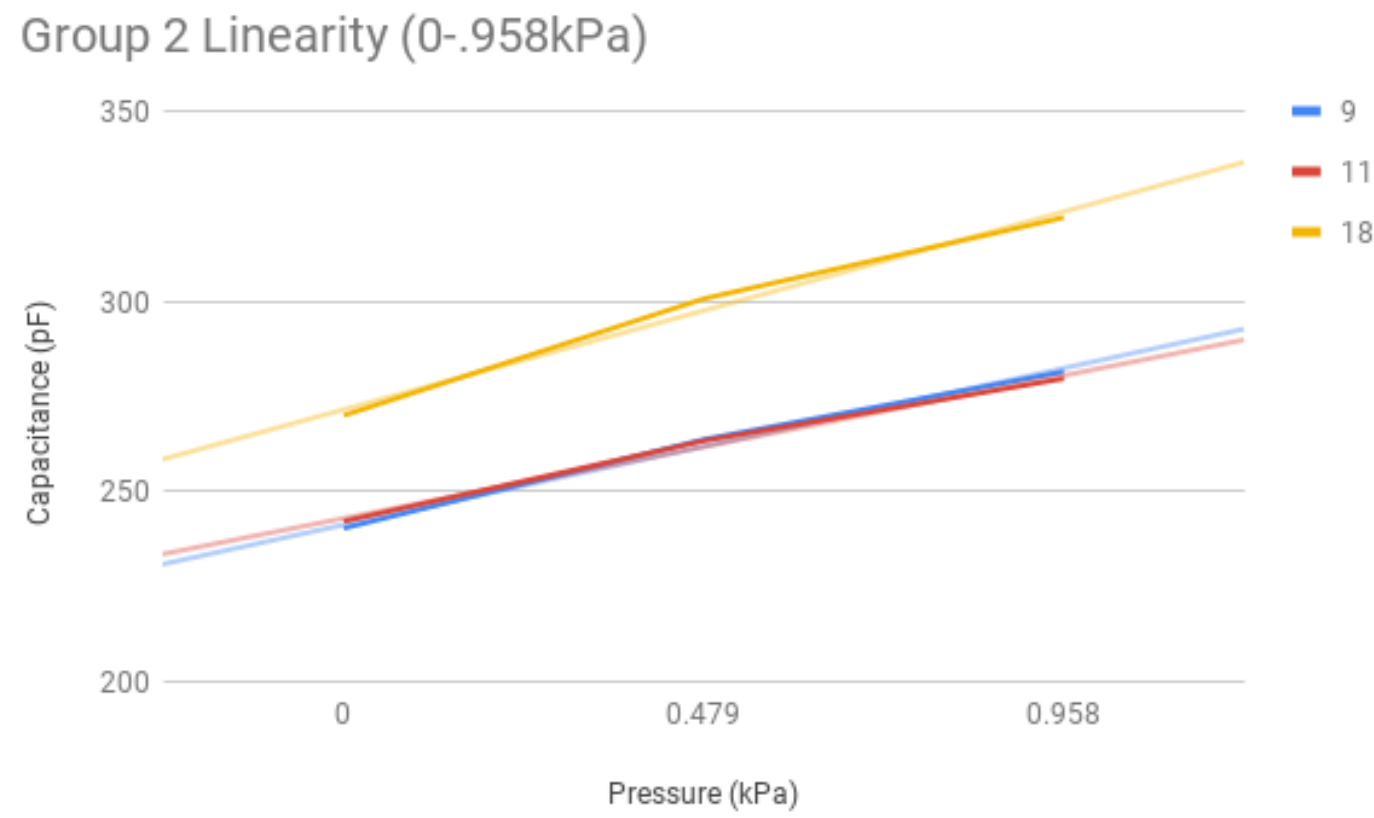


Figure 16. Graph of linearity for fabrics in Group 2 (1.44-3.83kPa).

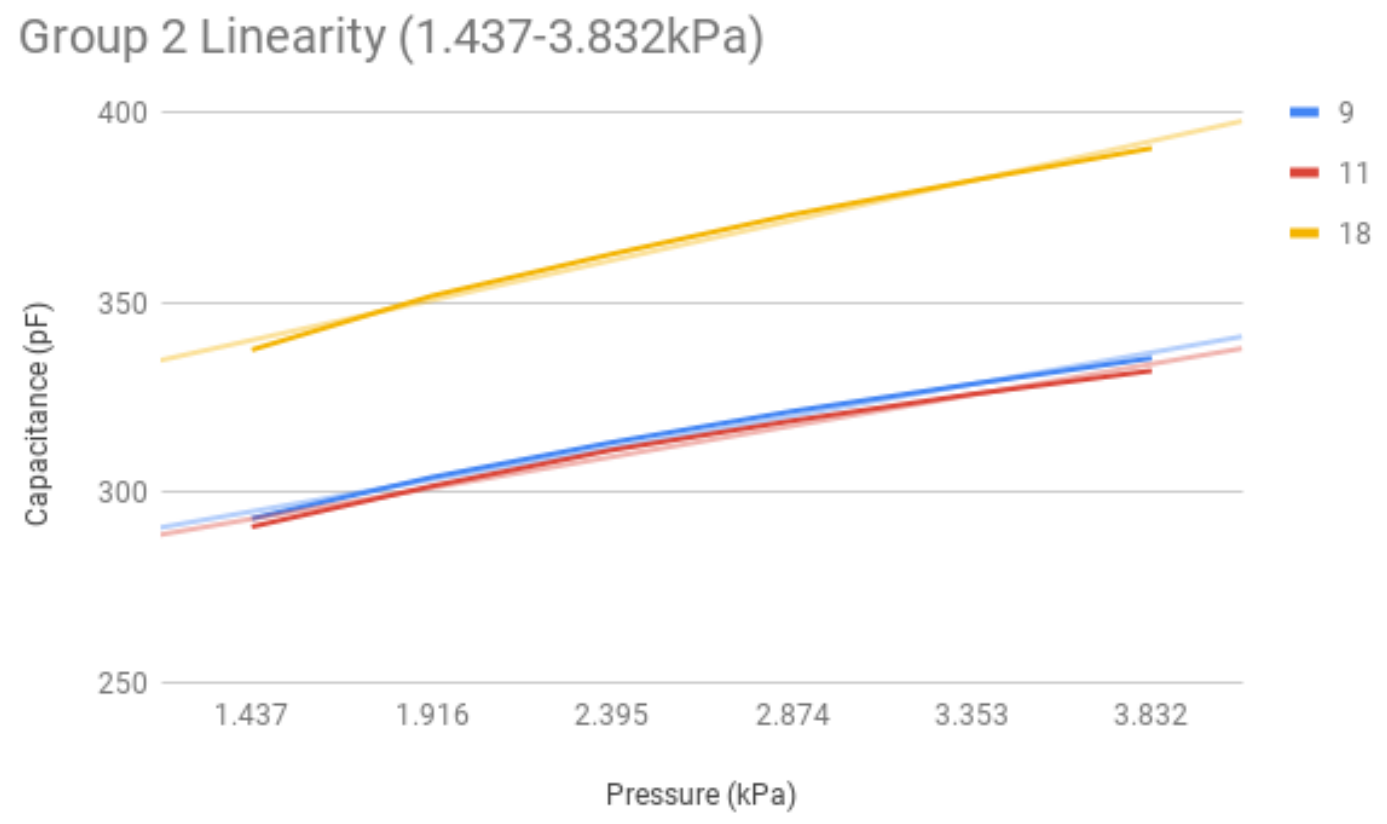

Figure 17. Graph of linearity for fabrics in Group $3(0-0.958 \mathrm{kPa})$.

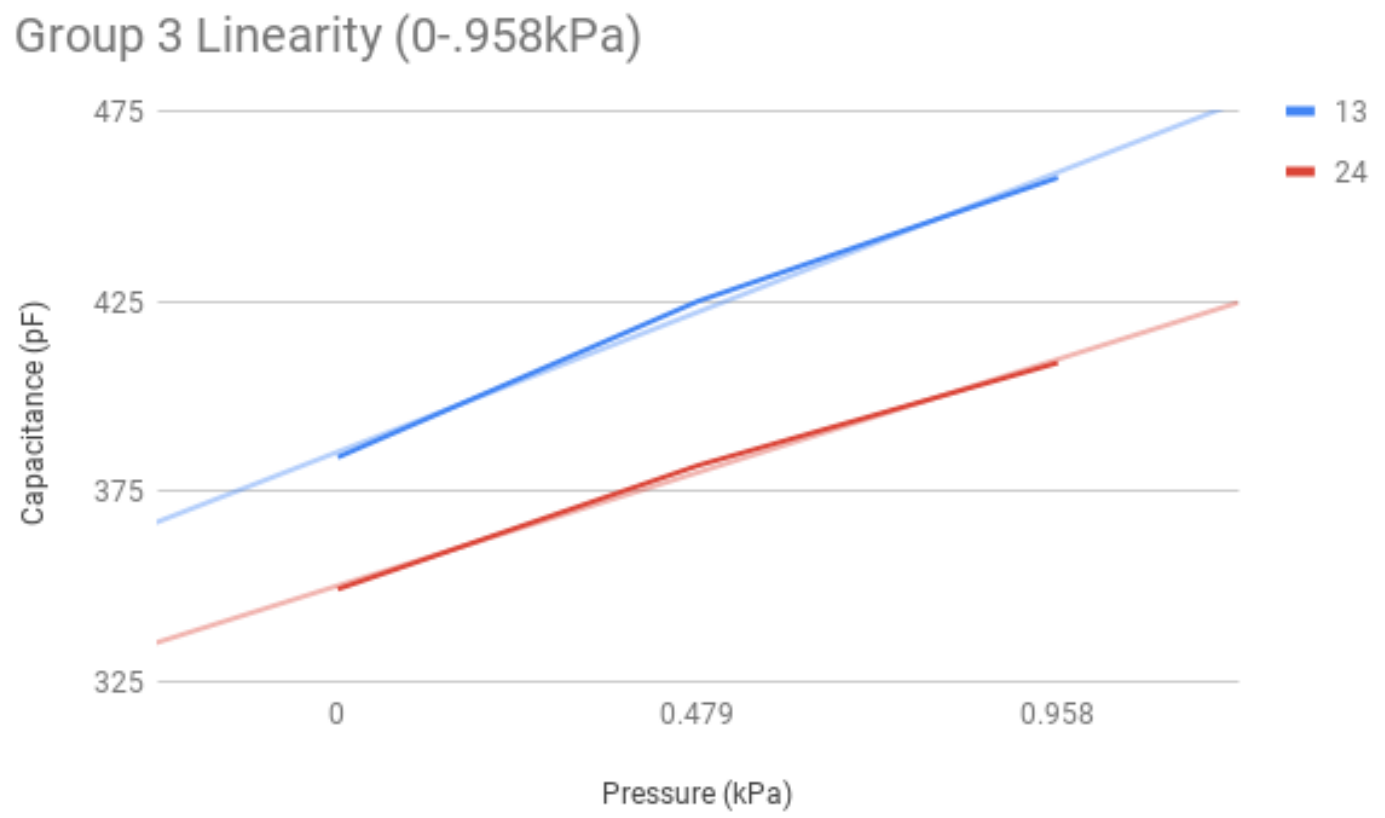


Figure 18. Graph of linearity for fabrics in Group 3 (1.44-3.83kPa).

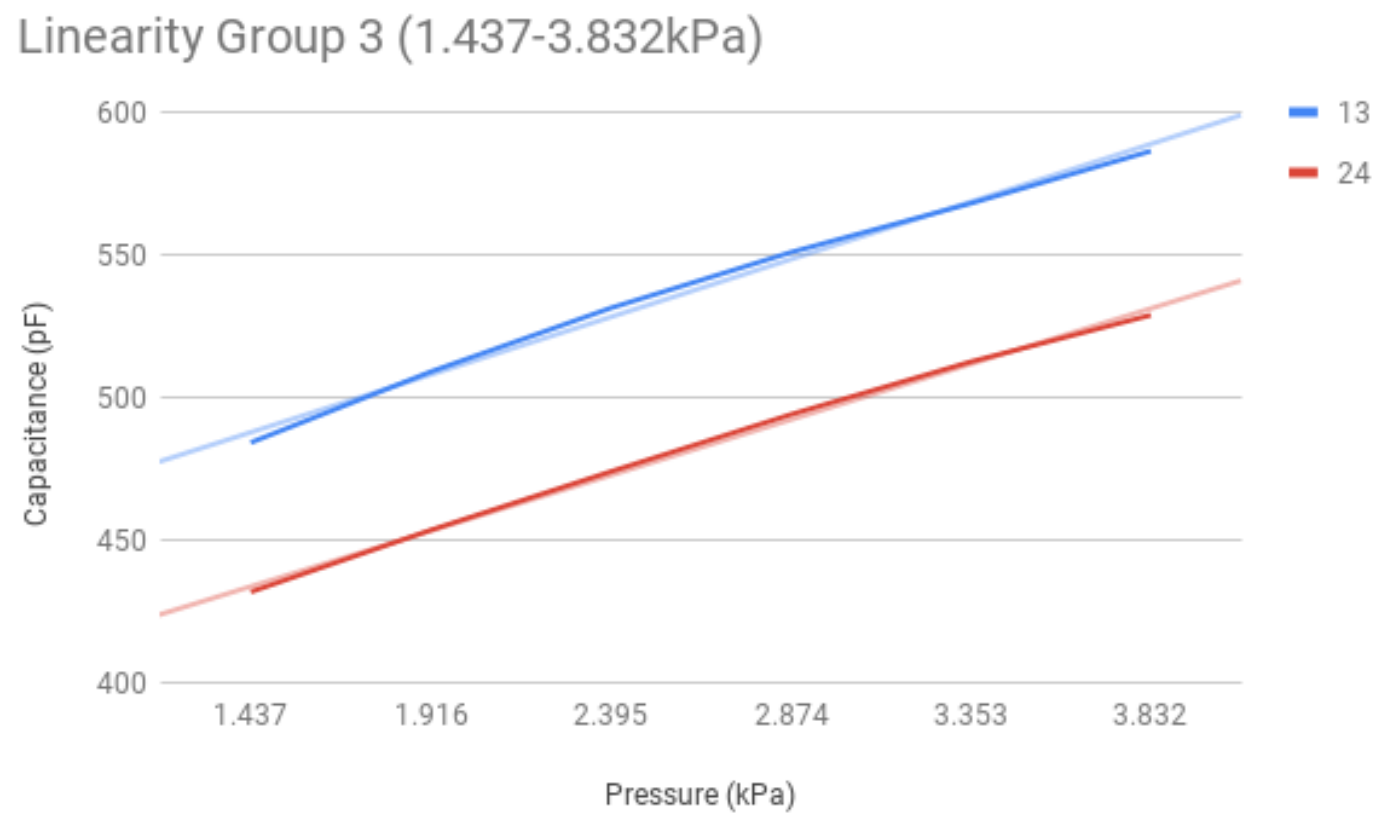

Figure 19. Graph of linearity for fabrics in Group 4 (0-0.958kPa).

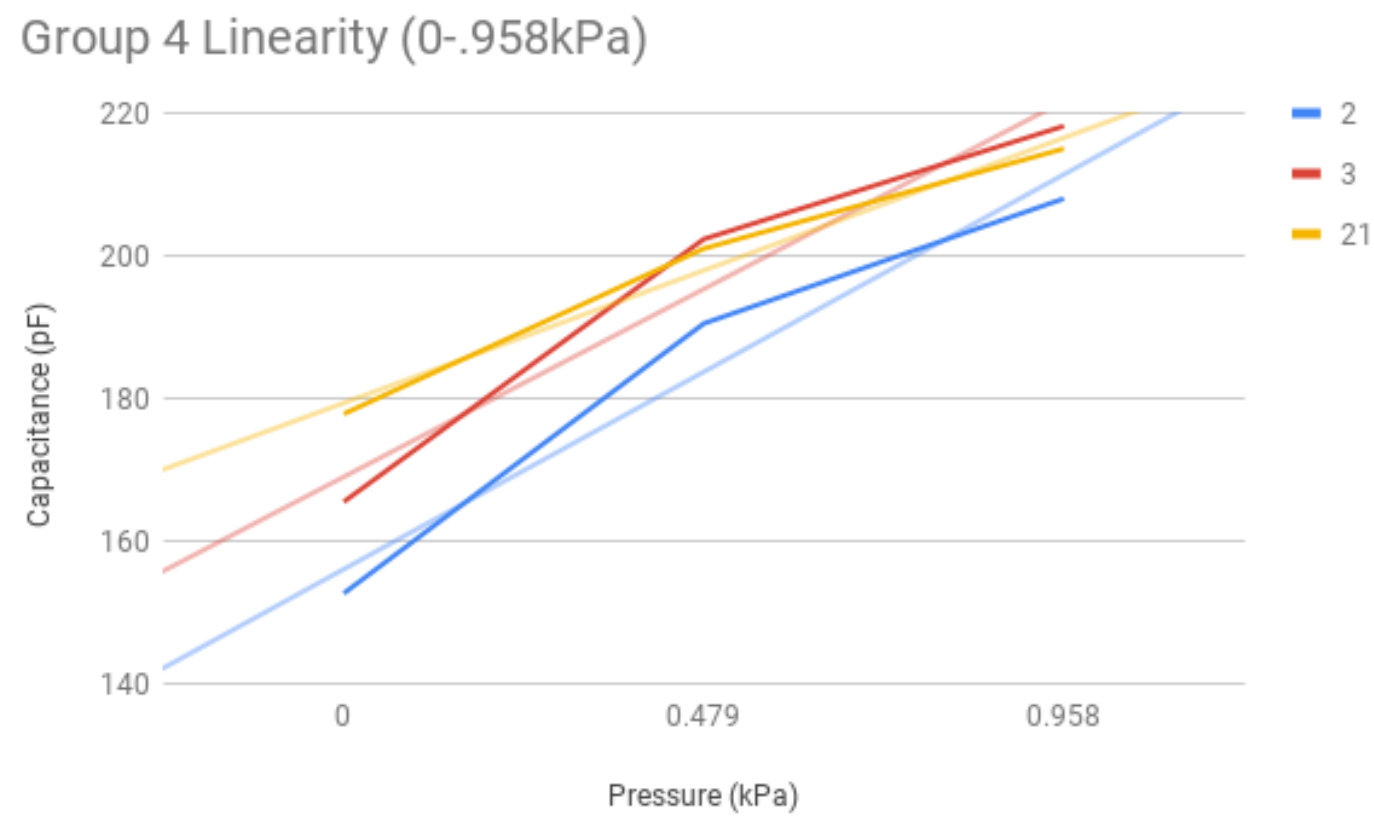


Figure 20. Graph of linearity for fabrics in Group 4 (1.44-3.83kPa).

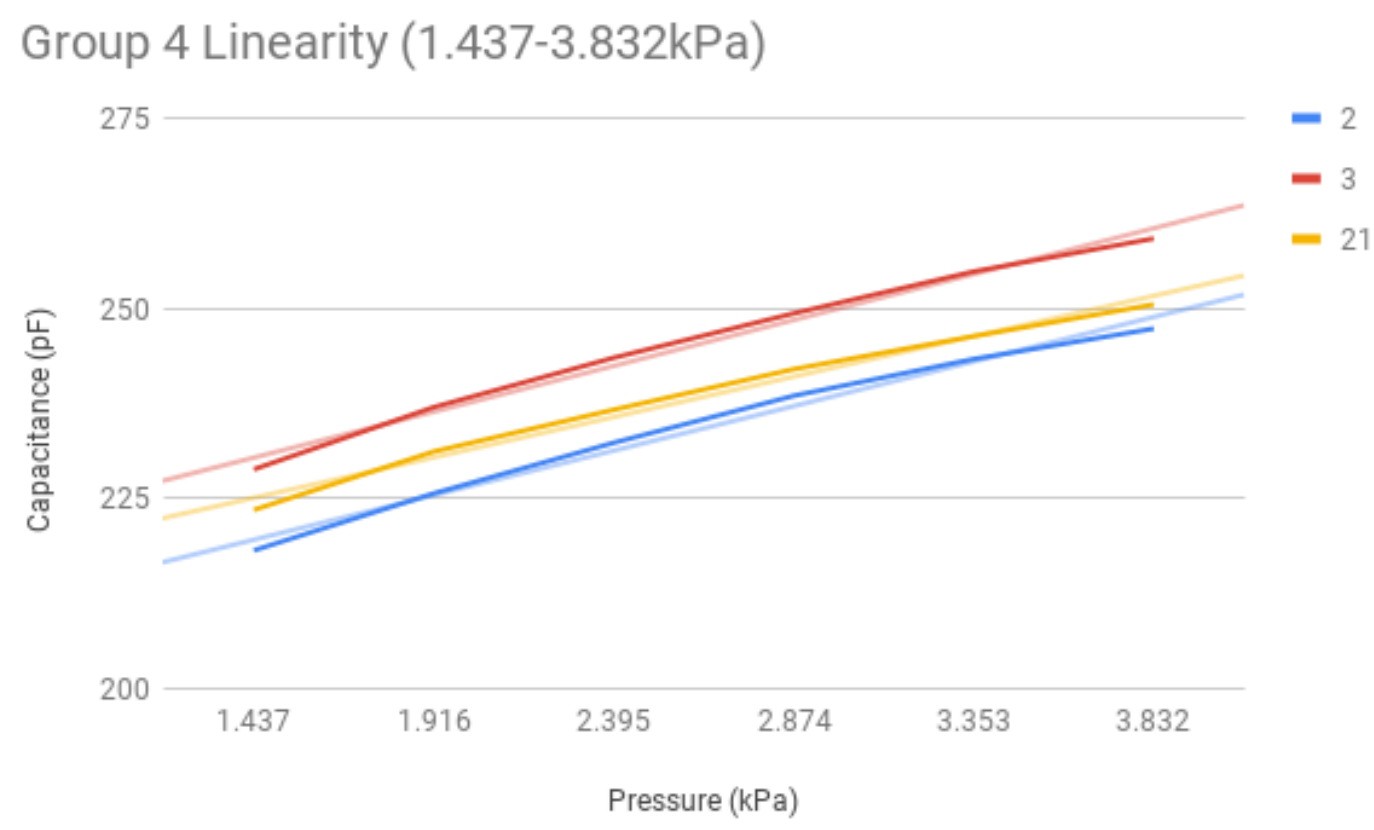

Table 6. Hysteresis error for fabrics in Groups 1-4.

\begin{tabular}{|c|c|c|c|c|c|c|c|}
\hline \begin{tabular}{l|} 
Group \\
1
\end{tabular} & & $\begin{array}{l}\text { Group } \\
2\end{array}$ & & \begin{tabular}{|l|} 
Group \\
3
\end{tabular} & & \begin{tabular}{|l|} 
Group \\
4
\end{tabular} & \\
\hline Fabric & $\begin{array}{l}\text { Hysteresis } \\
\text { error }\end{array}$ & Fabric & $\begin{array}{l}\text { Hysteresis } \\
\text { error }\end{array}$ & Fabric & $\begin{array}{l}\text { Hysteresis } \\
\text { error }\end{array}$ & Fabric & $\begin{array}{l}\text { Hysteresis } \\
\text { error }\end{array}$ \\
\hline 4 & $18.4 \%$ & 9 & $10.0 \%$ & 13 & $7.70 \%$ & 2 & $18.5 \%$ \\
\hline 10 & $10.0 \%$ & 11 & $7.80 \%$ & 24 & $7.10 \%$ & 3 & $19.0 \%$ \\
\hline 12 & $19.5 \%$ & 18 & $7.60 \%$ & & & 21 & $16.1 \%$ \\
\hline 19 & $16.2 \%$ & & & & & & \\
\hline
\end{tabular}


Figure 21. Graph of hysteresis error for fabrics in Group 2.

\section{Group 2 Hysteresis}

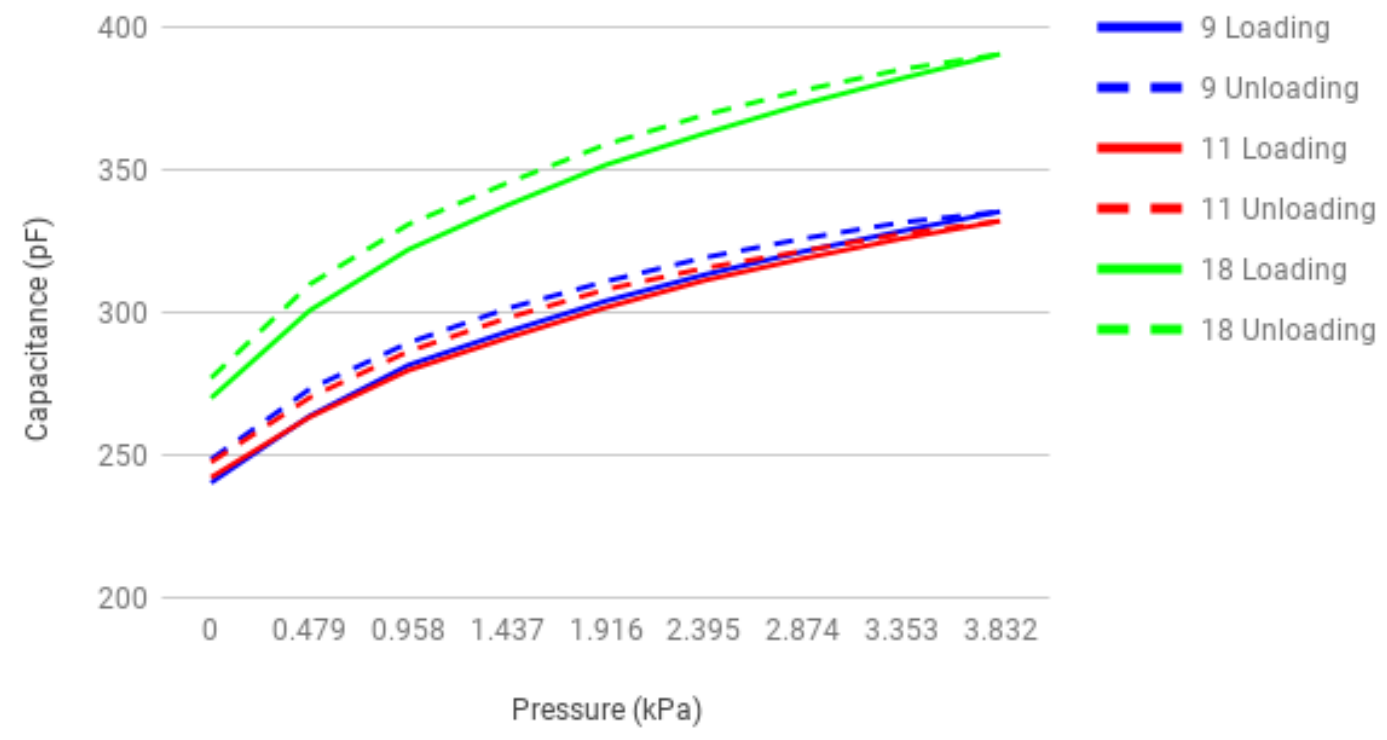

Figure 22. Graph of hysteresis error for fabrics in Group 3.

\section{Group 3 Hysteresis}

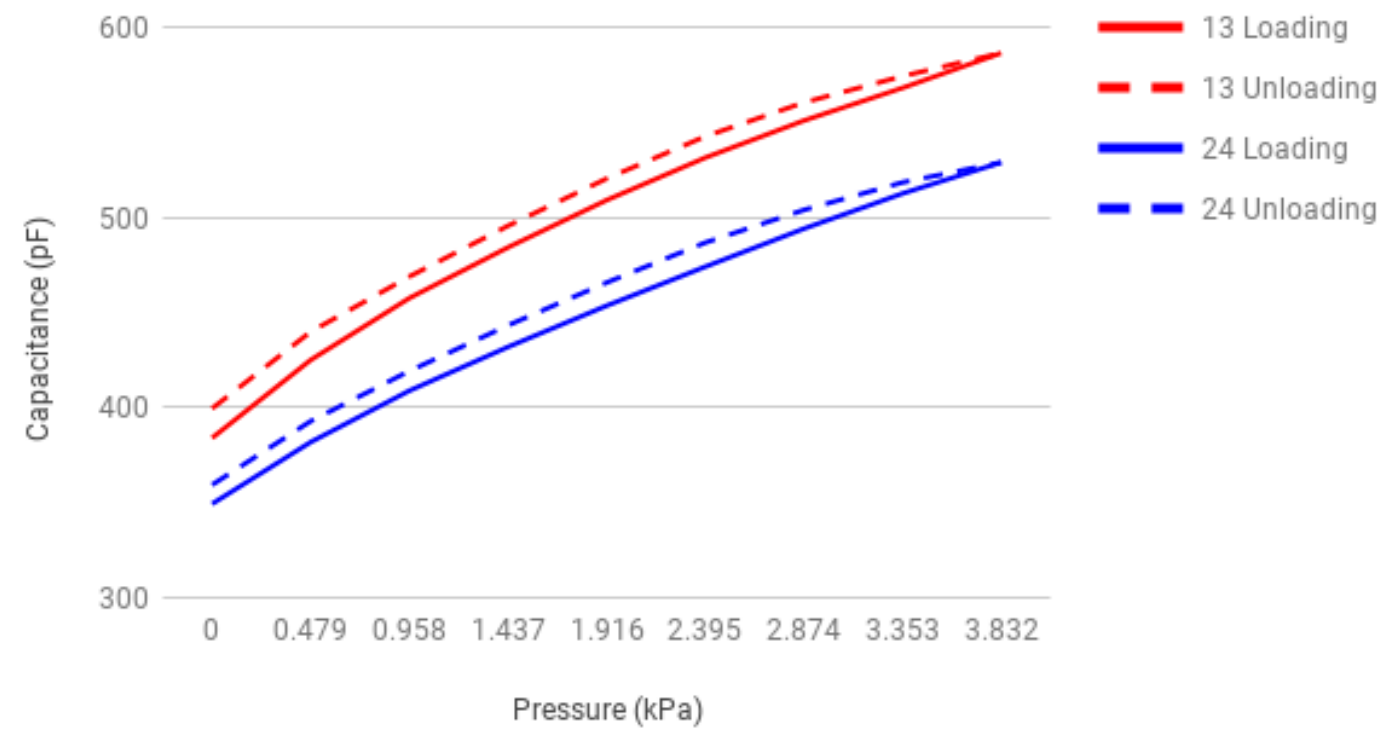


Figure 23. Graph of hysteresis error for fabrics in Group 4.

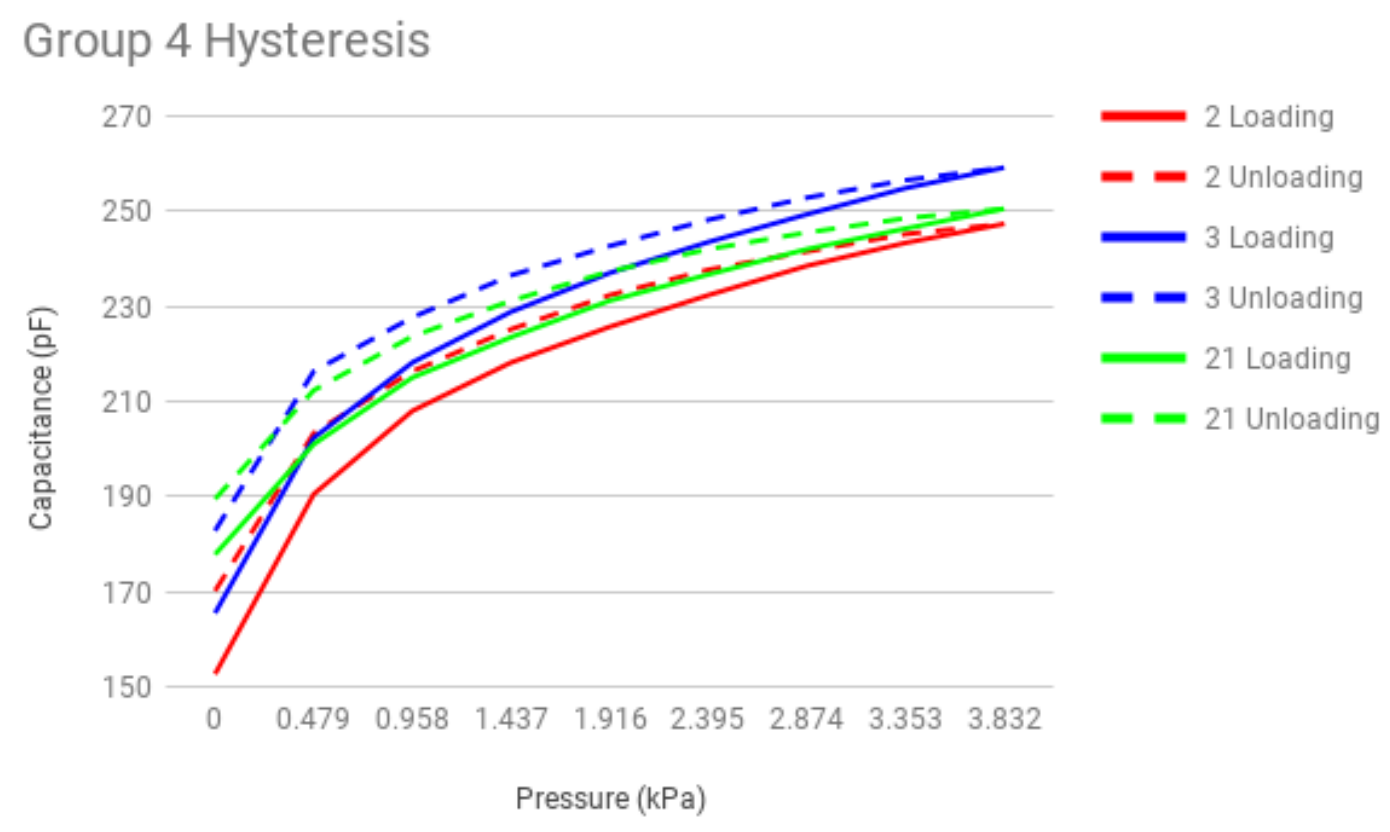

Table 7. Repeatability of fabrics in Groups 1-4.

\begin{tabular}{|c|c|c|c|c|c|c|c|}
\hline \begin{tabular}{|l|} 
Group \\
1
\end{tabular} & & \begin{tabular}{|l|} 
Group \\
2
\end{tabular} & & \begin{tabular}{|l|} 
Group \\
3
\end{tabular} & & \begin{tabular}{|l|} 
Group \\
4
\end{tabular} & \\
\hline $\begin{array}{l}\text { Fabric } \\
\#\end{array}$ & $\begin{array}{l}\text { SD } \\
\text { mean } \\
(\mathrm{pF})\end{array}$ & $\begin{array}{l}\text { Fabric } \\
\#\end{array}$ & $\begin{array}{l}\text { SD } \\
\text { mean } \\
(\mathrm{pF})\end{array}$ & $\begin{array}{l}\text { Fabric } \\
\#\end{array}$ & $\begin{array}{l}\text { SD } \\
\text { mean } \\
(\mathrm{pF})\end{array}$ & $\begin{array}{l}\text { Fabric } \\
\#\end{array}$ & $\begin{array}{l}\text { SD } \\
\text { mean } \\
(\mathrm{pF})\end{array}$ \\
\hline 4 & 13.6 & 9 & 3.18 & 13 & 8.27 & 2 & 4.86 \\
\hline 10 & 1.96 & 11 & 2.52 & 24 & 14.6 & 3 & 7.31 \\
\hline 12 & 4.31 & 18 & 7.39 & & & 21 & 2.71 \\
\hline 19 & 2.73 & & & & & & \\
\hline
\end{tabular}


Figure 24. Repeatability of fabrics in Group 1.

Group 1 Repeatability

400

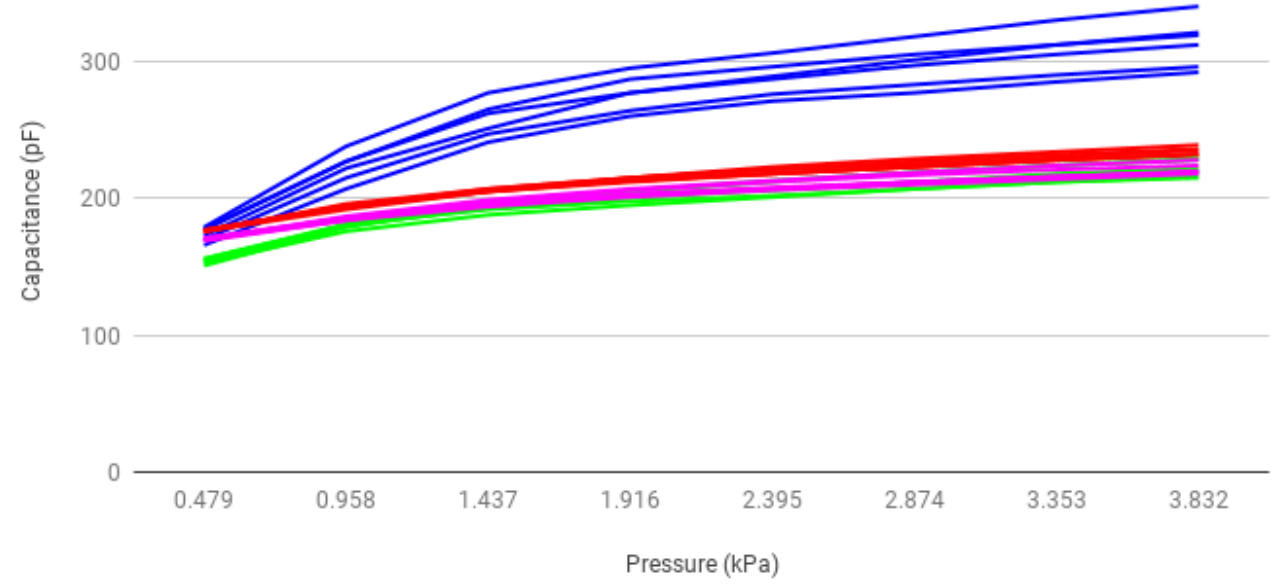

Figure 25. Repeatability of fabrics in Group 2.

Group 2 Repeatability

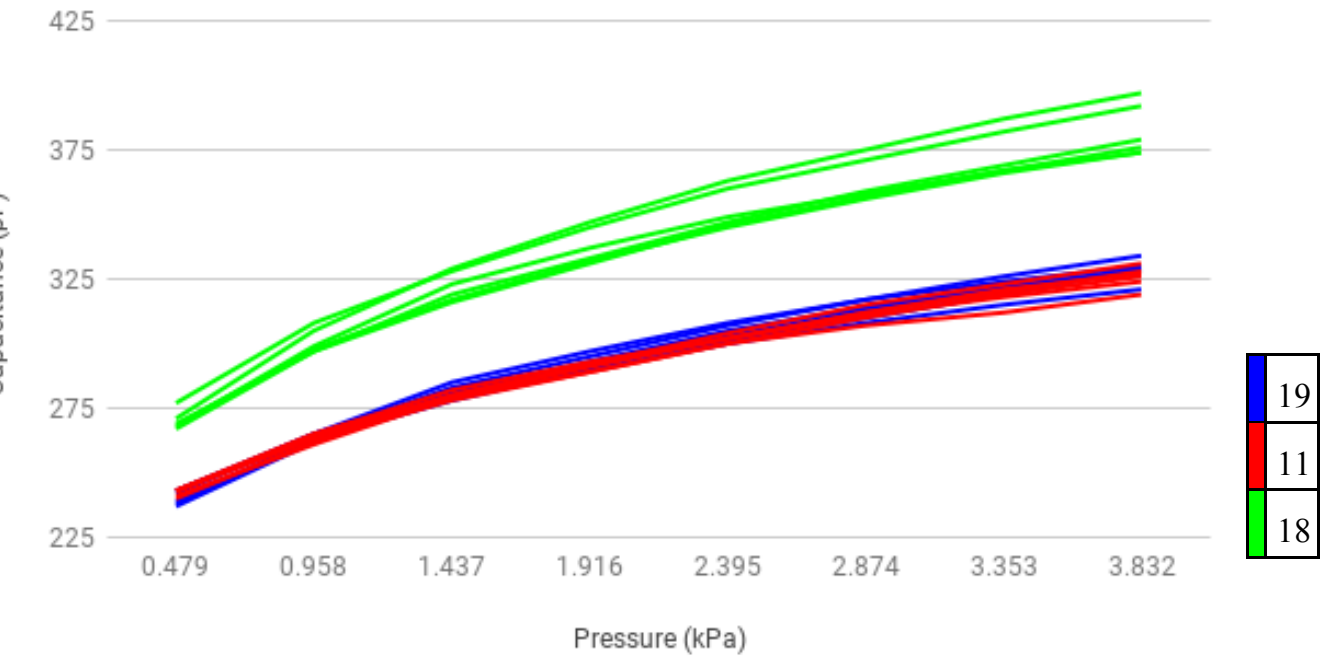


Figure 26. Repeatability of fabrics in Group 4.

Group 4 Repeatability

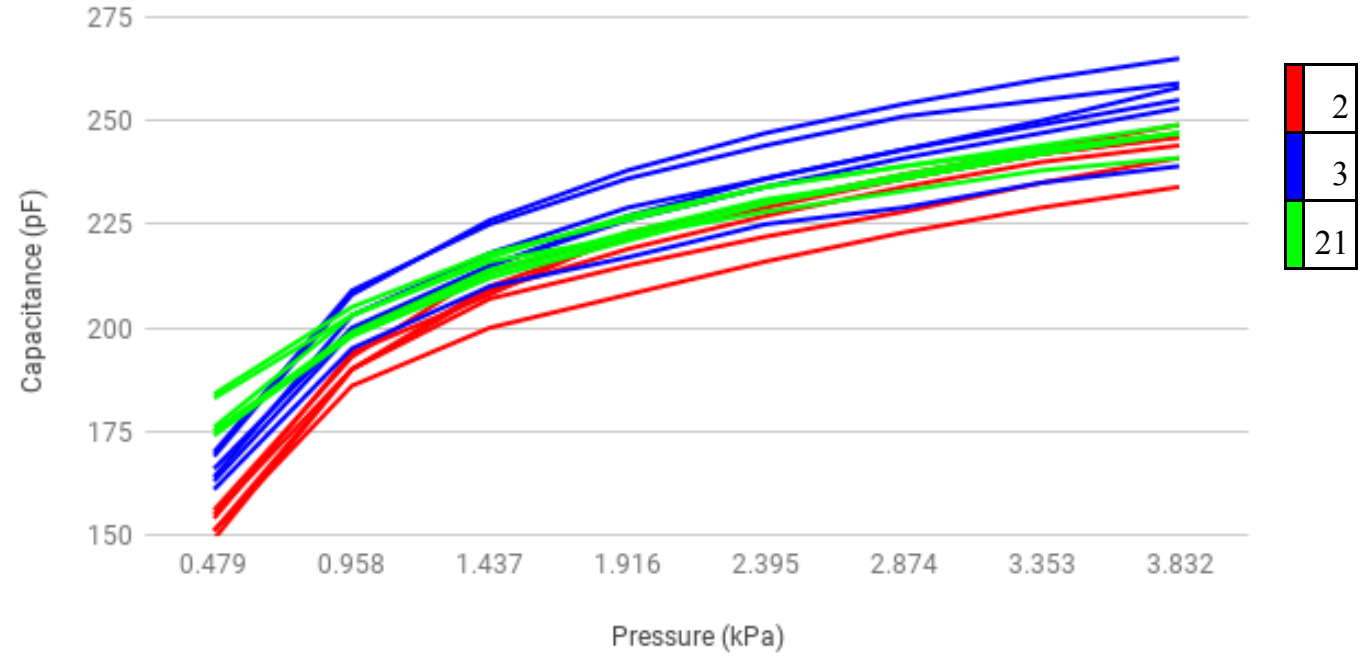




\section{BIBLIOGRAPHY}

1. Z. He, W. Chen, B. Liang, C. Liu, L. Yang, D. Lu, Z. Mo, H. Zhu, Z. Tang and X. Gui, "Capacitive Pressure Sensor with High Sensitivity and Fast Response to Dynamic Interaction Based on Graphene and Porous Nylon Networks", ACS Applied Materials \& Interfaces, vol. 10, no. 15, pp. 12816-12823, 2018.

2. J. Hayward, "E-Textiles 2018-2028: Technologies, Markets and Players: IDTechEx", IDTechEx, 2018. [Online]. Available: https://www.idtechex.com/research/reports/e-textiles-2018-2028-technologiesmarkets-and-players-000613.asp. [Accessed: 16- Dec- 2018].

3. "Global Smart Fabrics Market: Forecasts (2018-2023)". Mordorintelligence.com. 2018. [Online]. Available: https://www.mordorintelligence.com/industryreports/global-smart-fabrics-market-industry . \{Accessed: 16-Dec-2018].

4. M. Syduzzaman, S. Patwary, K. Farhana and S. Ahmed, "Smart Textiles and Nano-Technology: A General Overview", Journal of Textile Science \& Engineering, vol. 05, no. 01, 2015.

5. J. Meyer, B. Arnrich, J. Schumm and G. Troster, "Design and Modeling of a Textile Pressure Sensor for Sitting Posture Classification", IEEE Sensors Journal, vol. 10, no. 8, pp. 1391-1398, 2010.

6. A. Fiorillo, C. Critello and S. Pullano, "Theory, technology and applications of piezoresistive sensors: A review", Sensors and Actuators A: Physical, vol. 281, pp. 156-175, 2018.

7. N. Sarink, "Characterization and Manufacturing of Textile Pressure Sensors based on Piezoelectric Fibres", Master's Thesis, The Swedish School of Textiles, 2014.

8. S. Park, P. Das and J. Park, "Development of wearable and flexible insole type capacitive pressure sensor for continuous gait signal analysis", Organic Electronics, vol. 53, pp. 213-220, 2018.

9. S. Chen and X. Guo, "Improving the Sensitivity of Elastic Capacitive Pressure Sensors Using Silver Nanowire Mesh Electrodes", IEEE Transactions on Nanotechnology, vol. 14, no. 4, pp. 619-623, 2015.

10. V. Mitrakos, L. Macintyre, F. Denison, P. Hands and M. Desmulliez, "Design, Manufacture and Testing of Capacitive Pressure Sensors for Low-Pressure Measurement Ranges", Micromachines, vol. 8, no. 2, p. 41, 2017. 
11. E. Terzic, "Capacitive Sensing Technology", in A Neural Network Approach to Fluid Quantity Measurement in Dynamic Environments, 1st ed., E. Terzic, J. Terzic, R. Nagarajah and M. Alamgir, Ed. London: Springer-Verlag, 2012, pp. $11-15$.

12. O. Atalay, A. Atalay, J. Gafford and C. Walsh, "A Highly Sensitive CapacitiveBased Soft Pressure Sensor Based on a Conductive Fabric and a Microporous Dielectric Layer", Advanced Materials Technologies, vol. 3, no. 1, p. 1700237, 2017.

13. S. Malik, R. Kocaman, H. Kaynak, T. Gereke, D. Aibibu, O. Babaarslan and C. Cherif, "Analysis and prediction of air permeability of woven barrier fabrics with respect to material, fabric construction and process parameters", Fibers and Polymers, vol. 18, no. 10, pp. 2005-2017, 2017.

14. A. Asayesh, F. Mirgoli and A. Gholamhosseini, "An investigation into the effect of fabric structure on the compressional properties of woven fabrics", The Journal of The Textile Institute, vol. 109, no. 1, pp. 32-38, 2017.

15. T. Kuphaldt, Lessons In Electric Circuits, Volume I-DC, 5th ed. 2006, pp. 470471.

16. H. Zhang, X. Tao, T. Yu, S. Wang and X. Cheng, "A novel sensate 'string' for large-strain measurement at high temperature", Measurement Science and Technology, vol. 17, no. 2, pp. 450-458, 2006.

17. T. Ogulata, "Air Permeability of Woven Fabrics", Journal of Textile and Apparel, Technology and Management, vol. 5, no. 2, 2006.

18. E. Taştan Özkan, M. Akgun, A. Gurarda and S. Omeroglu, "Investigation of the effect of different structural parameters of cotton woven fabrics on their air permeability", IOP Conference Series: Materials Science and Engineering, vol. 254, p. 182014, 2017.

19. R. Gong and X. Chen, "Technical Yarns", in Handbook of Technical Textiles: Technical Textile Processes, 2nd ed., A. Horrocks and S. Anand, Ed. Cambridge: Woodhead Publishing, 2015, pp. 56-57.

20. A. Mukhopadyhay, A. Dash and V. Kothari, "Thickness and compressional characteristics of air-jet textured yarn woven fabrics", International Journal of Clothing Science and Technology, vol. 14, no. 2, pp. 88-99, 2002.

21. M. Havlová, "Air Permeability and Costructional Parameters of Woven Fabrics", FIBRES \& TEXTILES in Eastern Europe, vol. 21, no. 2, pp. 84-89, 2013. 
22. AATCC TM20-2013, Fiber Analysis: Qualitative. Developed in 1955 by AATCC Committee RA24 (revised 2013)

23. ASTM D1777-96(2015), Standard Test Method for Thickness of Textile Materials, ASTM International, West Conshohocken, PA, 2015, www.astm.org

24. ASTM D3775-17e1, Standard Test Method for End (Warp) and Pick (Filling) Count of Woven Fabrics, ASTM International, West Conshohocken, PA, 2017, www.astm.org

25. ASTM D3774-18, Standard Test Method for Width of Textile Fabric, ASTM International, West Conshohocken, PA, 2018, www.astm.org

26. ASTM D3776 / D3776M-09a(2017), Standard Test Methods for Mass Per Unit Area (Weight) of Fabric, ASTM International, West Conshohocken, PA, 2017, www.astm.org

27. ASTM D1776 / D1776M-16, Standard Practice for Conditioning and Testing Textiles, ASTM International, West Conshohocken, PA, 2016, www.astm.org

28. ASTM D737-18, Standard Test Method for Air Permeability of Textile Fabrics, ASTM International, West Conshohocken, PA, 2018, www.astm.org

29. X. Lü, J. Jiang, H. Wang, Q. Gao, S. Zhao, \& N. Li, "Sensitivity-Compensated Micro-Pressure Flexible Sensor for Aerospace Vehicle", Sensors, vol. 19, no. 1, p. 72, 2018.

30. F. Pizarro, P. Villavicencio, D. Yunge, M. Rodríguez, G. Hermosilla and A. Leiva, "Easy-to-Build Textile Pressure Sensor", Sensors, vol. 18, no. 4, p. 1190, 2018.

31. S. Min, Y. Yun and H. Shin, "Simplified Structural Textile Respiration Sensor Based on Capacitive Pressure Sensing Method", IEEE Sensors Journal, vol. 14, no. 9, pp. 3245-3251, 2014. Available: 10.1109/jsen.2014.2327991

32. J. Saenz-Cogollo, M. Pau, B. Fraboni and A. Bonfiglio, "Pressure Mapping Mat for Tele-Home Care Applications", Sensors, vol. 16, no. 3, p. 365, 2016. Available: $10.3390 / \mathrm{s} 16030365$.

33. Y. Enokibori, Y. Shimakami, A. Suzuki, K. Mase and H. Mizuno, "E-textile Pressure Sensor Based on Conductive Fiber and Its Structure", in Conference on Pervasive and Ubiquitous Computing, Zurich, 2013, pp. 207-210. 